\title{
A Bioeconomic Approach to Marriage and the Sexual Division of Labor
}

\author{
Michael Gurven • Jeffrey Winking • \\ Hillard Kaplan • Christopher von Rueden • \\ Lisa McAllister
}

Published online: 23 April 2009

(C) The Author(s) 2009. This article is published with open access at Springerlink.com

\begin{abstract}
Children may be viewed as public goods whereby both parents receive equal genetic benefits yet one parent often invests more heavily than the other. We introduce a microeconomic framework for understanding household investment decisions to address questions concerning conflicts of interest over types and amount of work effort among married men and women. Although gains and costs of marriage may not be spread equally among marriage partners, marriage is still a favorable, efficient outcome under a wide range of conditions. This bioeconomic framework subsumes both cooperative and conflictive views on the sexual division of labor. We test hypotheses concerning marriage markets, assortative mating, and men's labor motivations among Tsimane forager-horticulturalists of Bolivia and find that: (1) men and women both value work effort in marital partners, (2) marital labor contributions are complementary, (3) work effort is correlated between spouses, (4) total production is correlated with total reproduction, and (5) better hunters have higher fitness gains within marital unions.
\end{abstract}

Keywords Sexual division of labor · Family $\cdot$ Marriage $\cdot$ Bargaining $\cdot$ Behavioral ecology Tsimane

\footnotetext{
M. Gurven $(\bowtie) \cdot$ C. von Rueden $\cdot$ L. McAllister

Department of Anthropology, University of California-Santa Barbara, Santa Barbara,

CA 93106, USA

e-mail: gurven@anth.ucsb.edu

C. von Rueden

e-mail: vonrueden@umail.ucsb.edu

L. McAllister

e-mail: 1sheina@hotmail.com

J. Winking

Department of Anthropology, Texas A\&M University, College Station, TX 77843-4352, USA

e-mail: jeff.winking@comcast.net

H. Kaplan

Department of Anthropology, University of New Mexico, Albuquerque, NM 87131, USA

e-mail: hkaplan@unm.edu
} 
In one of the first systematic cross-cultural surveys of hunter-gatherer societies, Ember (1978) found that only men hunt in 166 of 179 societies, both men and women hunt in 13 societies, and in no societies do only women hunt, whereas women are the main gatherers in two-thirds of these societies. In a wider range of traditional societies, other tasks, such as ore smelting, metalworking, and lumbering, are also exclusively male activities, while preparation of vegetables, cooking, and bringing water are predominantly or exclusively performed by women (Murdock and Provost 1973: Table 1). Numerous explanations for a sexual division of labor have been offered over the years, including those that emphasize patriarchy and ideology, biological or physical capabilities and/or limitations, disparate reproductive strategies, and coordination and economic efficiency. Recent treatments justify the existence of pair bonds, test the evolutionary significance of why men often choose high-variance production activities and women low-variance activities, and explain cross-cultural variation in divorce frequency (Bliege Bird 1999; Marlowe 2007; Panter-Brick 2002; Quinlan and Quinlan 2007). An earlier paper attempted to explain the allocation of household tasks among male and female family members of different ages (Gurven and Kaplan 2006).

Here we continue this line of inquiry using economic bargaining models but with an evolutionary spin. We make no attempt to explain why men or women engage in certain tasks in some populations but not in others, why divorce may be more or less common in different populations, or how historical factors and cultural norms impact temporal changes in the sexual division of labor. Instead, we focus on the following central question: What impacts the relative amount of work effort that each partner invests in household labor?

To investigate this question, we describe an approach elaborated in Gurven and Hill (2009) and Gurven and von Rueden (2006) that attempts to ( $a$ ) establish a theoretical justification for an intra-familial division of labor, $(b)$ build a conceptual framework for understanding gendered roles in a division of labor that includes both private and shared fitness interests across the life course, and (c) improve understanding of power dynamics over the lifespan of households. Our approach borrows from economic models of marriage markets (Becker 1973, 1974), sexual division of labor (Hadfield 1999), household time and resource allocation under divorce-threat bargaining (Manser and Brown 1980; McElroy and Horney 1981), and "separate spheres" bargaining (Lundberg and Pollak 1993, 1994). In these models, rational individuals gain more utility as a joint economic unit than from remaining single; utility derives from a combination of household (including offspring) and market production. Wage rates increase with human capital investment, and marriage markets govern the matching of potential spouses.

By focusing on combined "utility" of a joint unit, economic models do not consider the fitness consequences of each partner's activities within and outside the marriage. An evolutionary interpretation is that men and women engage in pair bonds (i.e., marriage) to achieve fitness benefits through the joint production of offspring, and that joint production produces an economy of scale so that the production of the pair is greater than the summed production of individuals working by themselves (Kaplan and Lancaster 2003). Unlike in the economic model, however, males and females can also gain fitness benefits from time and resources spent outside the union. One or both partners may reduce investments in the union, and/or disproportionately consume within-family resources. The proposed bargain- 
ing framework therefore subsumes cooperative and conflictive gender relations within marital unions.

Although we focus on hunter-gatherers and forager-farmers under natural fertility conditions, our basic framework is general and can be developed to help understand gendered work effort in other types of societies. Here, however, we test predictions using data collected among the mildly polygynous Tsimane forager-horticulturalists of Bolivia. We show that productivity is a vital component of mate value; total work effort is correlated among marital partners; work effort is relatively equal, but spent in complementary, coordinated tasks between spouses; higher productive gains are associated with higher reproductive gains; and, to some extent, within-pair household dynamics are influenced by differential mate value between spouses.

\section{Why the Sexual Division of Labor in the First Place?}

Elsewhere (Gurven and Hill 2009; Gurven and Kaplan 2006; Gurven and von Rueden 2006) we have argued that four critical aspects of hunter-gatherer socioecology are responsible for the sexual division of labor among foragers: (1) high offspring dependency over a long period results in compound dependency of multiple offspring; (2) an adequate diet requires macronutrients that are typically found in foods typically procured by mutually exclusive means; (3) peak efficiency in many foraging activities is delayed owing to time-dependent learning; and (4) some tasks exhibit sexdifferentiated comparative advantage. These conditions are likely common to most foraging groups and are together responsible for a discrete sexual division of labor.

The average hunter-gatherer woman can expect to have five or six children over her lifetime (Bentley et al. 1993; Hewlett 1991), with some groups like the Ache of Paraguay showing higher fertility (Total Fertility Rate $[$ TFR $]=8$ ). Human children grow and develop very slowly and consume more food than they produce well into their mid- to late teens (Kaplan 1994; Kramer 2005). Throughout a woman's reproductive life, she is therefore likely to have multiple offspring at varying degrees of dependency. Even at ages of peak adult production, few women or men would be able to feed themselves and all of their children without assistance from others (see Gurven and Walker 2006 for estimates of age-specific dependency for low- and high-fertility foragers). Meeting the high net caloric demand of children puts a premium on cooperative arrangements that increase efficiency of production and promote resource provisioning. Nuclear families are one possible arrangement, and perhaps a minimally sized one providing fairly consistent and reliable consumption. Also, depending on the environment, the nuclear family may be somewhat selfsufficient, given the fission and fusion behavior of small groups whose larger composition may change periodically (Kelly 1983).

Offspring need alone, however, is insufficient to promote specialization in subsistence activities by sex or age. The macronutrient composition of foods and the strategies used to acquire them also matter. Despite little consensus over the optimal combination of lipids, proteins, and carbohydrates that should be consumed daily to best promote growth, health, and fecundity, all three are necessary for healthy growth, development, body maintenance, and reproduction (see Demment et al. 2003 and citations therein). A great deal of evidence suggests that protein-lipid 
resources and additional animal source micronutrients are often limiting factors in people's diets and hence more valuable than carbohydrates in many human societies. Many studies show that increases in proteins and lipids lead to improved growth and health in human societies (Larsen 2003). High protein-lipid foods are also critical in brain growth, immune function development, and female reproductive function (Milton 2003; Neumann et al. 2003). The human gut appears obligatorily designed to eat a mixed macronutrient diet (Aiello and Wheeler 1995), and biochemical evidence suggests that several essential amino acids (e.g., taurine, 20- and 22-carbon fatty acids) are only obtained from consumption of animal tissue (Cordain et al. 2001).

Economic strategies must therefore produce complementary amounts of carbohydrates and protein-lipids (and probably other micronutrients). Most roots, fruits, shoots, berries, and other plant and vegetable products tend to be high in carbohydrates, sugars, and micronutrients but low in fats and proteins. Similarly, meat from wild game, shellfish, and other kinds of fish are high in protein, and animal organs, bone marrow, and brains are especially rich sources of lipids, but all are poor sources of carbohydrates. Separate macronutrients tend to be packaged in different foods so that a variety of items must be included as part of the human omnivore diet (see Harris and Ross 1987). Game, fish, roots, fruits, honey, nuts, insect larvae, berries, and other items common to forager diets are acquired by very different techniques, and each requires specific knowledge. Whereas many foods in foraging societies are difficult to acquire and require substantial learning, thereby contributing to the dependency of hunter-gatherer children and adolescents (Kaplan et al. 2000), many gathering, shellfish collecting, and fishing activities may be more strength- or size-dependent than skills-dependent, so reaching adult-level productivity in these activities may not be as difficult (Bird and Bliege Bird 2002, 2005; Tucker and Young 2005). In contrast, proficient hunting performance in several societies develops over long periods of time. Among Ache, Tsimane, and other hunting groups, making direct encounters with animals and killing them during pursuits are two difficult components of hunting that require a long time to reach peak skill levels (Gurven et al. 2006; Ohtsuka 1989; Walker et al. 2002).

When utility is provided by multiple foods, and acquisition of these foods requires separate subsistence strategies that may require substantial learning, and when increasing returns are gained with additional time investment, specialization is a likely, if not inevitable, outcome, even if all group members are equally capable of performing all tasks. Specialization maximizes household utility among cooperating individuals that divide their labor to obtain complementary objectives by increasing the proficiency with which tasks may be performed and by exploiting economies of scale. This is essentially Gary Becker's argument concerning familial division of labor applied to the hunter-gatherer context (see Becker 1991; Bergstrom 1997).

Specialization does not lead to the conclusion that men should hunt or fish and that women should gather or harvest. The sexes could coordinate on any complementary set of economic activities, as in the classic Battle of the Sexes game (Hadfield 1999; Rapoport 1966). Without increasing returns to specialization, both sexes could be generalists and freely alternate between complementary activities. A comparative advantage for one sex, however, coupled with a delayed learning curve, could push men in one direction and women in the other. Pregnancy and childcare constraints may be sufficient to give men a comparative advantage 
resulting in them being the sex that actively hunts (Hurtado et al. 1985; Lancaster 1978). The comparative advantage is further amplified by men's greater muscular strength and body size. Men may also gain mating benefits from hunting, and these may further motivate male hunting. However, these additional mating benefits are not necessary to explain why most men hunt in foraging societies (Gurven and von Rueden 2006). Instead, the signaling payoffs to hunting increase the overall returns to the activity, most likely increasing the likelihood that men will hunt exclusively or under conditions that might otherwise favor greater male involvement in gathering activities.

\section{Children as Public Goods: A Bargaining Approach}

Children can be viewed as a shared public good because they are a fitness outcome for both parents, regardless of the investment each of them provides. To model optimal parental investment, we consider partner fitness functions that contain shared household (or public) and personal (or private) components. The task is to determine an optimal set of time budget allocations for each marital partner and the resultant level of efficiency and equity in the distribution of gains. Two extreme possibilities include "symmetrical" marriages in which similar gains are realized by each partner and "dictatorial" marriages in which only one partner determines the allocations to both (Manser and Brown 1980). The existence of "deadbeat dads"-in other words, men who contribute little to marriage unions (particularly if such unions are dissolved) - does not negate the fact that an economy of scale associated with cooperation is an important feature of marriage unions; unstable unions and unequal bargaining power owing to unequal conditions or availability of outside options to each partner can lead to dissolved unions and/or a failure of one or both partners to invest in household production and childcare.

The optimal amount of time spent investing in offspring can be illustrated through the use of indifference curves. Each partner decides how much of their daily (waking) time budget to spend in each activity. For ease of presentation, we group all work activities into the category "household production" and all activities that yield private gain as "leisure." Work activities are those pertaining to direct resource acquisition (hunting, fishing, gathering, farming, wage labor), food preparation (butchering, cooking, cleaning, washing utensils, etc.), house maintenance (constructing houses, making fire, collecting firewood, getting water, etc.), and childcare activities (bathing, feeding, babysitting, etc.). Leisure includes social visits, relaxation and grooming, pursuing extra-pair relationships, play, or any other activity that does not provide utility to other household members.

The budget constraint is defined by the total number of hours that could be spent in either household production or leisure. If we plot household production on the $x$-axis and leisure (private goods) on the $y$-axis, the budget constraint line intersects the two axes at the point where all time would be dedicated only to that activity (Fig. 1). Usually a budget is a straight line, although it could bow outward if public and private activities can be performed simultaneously, as when hunting both feeds children and signals mate quality. Each partner maximizes the sum total of public and private fitness gains subject to budget constraints by choosing an optimal set of activities. These total fitness gains are likely to differ among husbands and wives, generating the potential for conflict. Convex isofitness curves describe combinations 


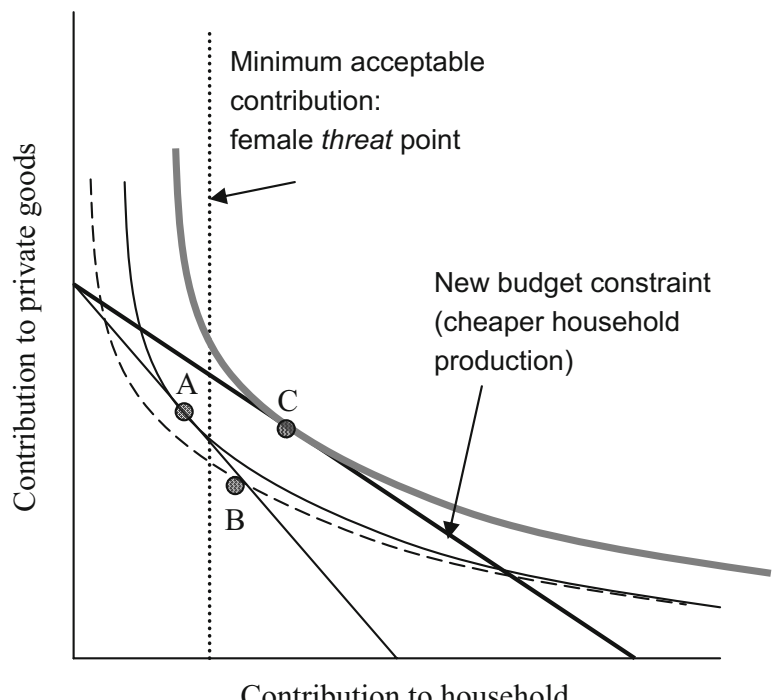

Fig. 1 Isofitness framework underlying a man's optimal mix of contributions to household and private goods. Straight diagonal lines represent budget constraints underlying a man's use of time. Point A is the optimal allocation of a man's time to household and private goods, but this point lies below the woman's minimum acceptable level of household contribution, or "threat point." Threat points are based on a spouse's opportunity costs to household contributions, where greater potential fitness gain outside the union raises one's threat point. A man will choose the suboptimal allocation at point B to avoid desertion by his wife. The thick black budget line illustrates the case where household goods are more cheaply acquired than with the thin black budget line. Under this scenario, the optimal mix is illustrated by point C. As noted in the text, the shape of indifference curves depends on several key functional relationships

of public and private goods that provide the same amount of returns in fitness (or some proxy) units. Decision makers therefore receive equal benefits from any combination of activities on the same curve. Curves more distant from the origin describe higher returns. The shape of these "indifference curves" depends on several key functional relationships, such as the shape of the fitness gains curve for investments in (1) childcare and provisioning of offspring, (2) mate acquisition, and (3) social status activities that provide both private benefits (e.g., mating benefits) and public benefits (e.g., deference). ${ }^{1}$

\footnotetext{
${ }^{1}$ The indifference curve approach is useful for looking at trade-offs and has been used to model women's optimal time allocation to childcare versus food production (Hurtado et al. 2006). Maynard Smith (1977) was the first to incorporate the trade-off between parenting and mate searching into a model of mate desertion (divorce). Empirical investigation of these two factors has been explored in several forager groups by Hurtado and Hill (1992) and Blurton Jones et al. (2000). When men's activities have only minimal impact on improving child welfare and mating opportunities are high (e.g., high operational sex ratio $=n$ reproductive-aged females $/ n$ adult males), pair bonds are expected to be brittle, divorce is likely, and male parental investment should be low. This theoretical model has been tested to some extent; however, the impact of men's parental investment has been measured mostly in extreme circumstances and using crude fitness measures, such as decrements to infant and child survival when a father dies or in father-absent households. Results show that the presence of a father can have a strong effect on children in hunter-gatherer societies where men's contribution to the diet is high (e.g., Ache), but the overall impact cross-culturally is variable and father presence appears to have little effect on child survivorship in most populations (Sear and Mace 2007). However, the presence of other kin who contribute aid during the absence of fathers makes exploration of true father effects difficult (Winking 2006).
} 
Partners do not make allocation decisions in isolation, so any consideration of optimal behavior for men must consider the decisions of women and vice versa. Any attempt to predict time budget decisions of men or women in isolation might lead to the result that both partners should become generalists, which as argued above is an inefficient outcome. Those considering marriage may have minimal expectations of household contribution from potential spouses. These can be considered "threat points," which describe a level of expected contributions by the partner and their presumed fitness effects; any level of effort below this threshold will result in dissolution of the marriage, or perhaps a shift in allocation of effort away from the household (Manser and Brown 1980). When a partner's opportunity costs to household investment are high owing to potential fitness gains outside the union (i.e., private good consumption), that partner's threat point should raise to help offset lost opportunities. Evidence for threat points is suggested by ethnographic documentation of commonly desired characteristics for marriage partners and by commonly listed causes of divorce (Betzig 1989). Studies among several tribal societies show that while men value physical attractiveness more than women, both partners are concerned that longterm mates display positive character traits, be hardworking, generous, and high producers (Hill and Hurtado 1996; Marlowe 2005; Pillsworth 2008). These traits only make sense if partners subscribe to the notion that the major gains from marriage are both productive and reproductive. If women did not gain from marrying men and were instead only gene-shopping, then we would expect much more polygyny than is observed among foragers, and only brittle pair bonds.

In the conceptual model, an initial allocation decision between public and private work effort is made by one partner, a reactionary allocation is made by the other partner, and so on until one of the following outcomes is reached: (1) both partners arrive at a stable equilibrium of contributions to the household; (2) the equilibrium is unstable and eventually one of the partners will contribute everything; or (3) one partner always defects and contributes nothing (Chase 1980). The second scenario suggests the downward spiral of a marriage heading for divorce, where lowering of investment by one partner results in an increase in the other partner's investment. For example, a man living matrilocally with his wife's kin may reduce investments in the family if he has access to extra-pair mating opportunities, while his wife may compensate with increased investments in the family. The third scenario should also result in divorce, except under the limiting case where the contributing partner has no other options. In this case, if the wife from the above example has no kin or other bargaining chips, she may always have to invest heavily in the household, regardless of the level of investment of her husband. At equilibrium, the second and third scenarios may result in the same unequal distribution of household contributions among partners. Usually the optimal time allocation for the male partner (point A in Fig. 1) will not match the solution that is optimal from the female point of view because husbands and wives share fitness gains only through public (household) and not private investments. The region between the optimal male and female solutions defines a set of time allocations for each sex that is subject to "negotiation." An important point to emphasize is that the final bargaining outcome does not have to ensure equal levels of contribution by men and women in marriage; rather it need only ensure that men and women both gain more from these unions than they would from alternative options. However, in a stable mating market where people tend to marry others of similar mate value (e.g., Schoen 
and Weinick 1993), differences in bargaining power might be small for a majority of couples, at least in the initial phase of marriage.

Marriage commitments are likely to be highest when children are young and partner reproductive value is high. Dwindling paternal investments may be expected some years after the initiation of marriage if payoffs to further investment are small, and if his partner's reproductive value has decreased. However, the high caloric demands of children and teenagers in a foraging environment often lasts until the youngest child is independent, well into parents' mid-forties and fifties (Gurven and Walker 2006; Winking et al. 2007). Increasing child survival through provisioning during the high-risk years of infancy and childhood (about $50 \%$ of hunter-gatherers survive to age 15: Gurven and Kaplan 2007) is only one way that fathers contribute to the welfare of their families. Fathers also foster transmission of cultural and ecological knowledge, facilitate alliances, and provide social support during conflict and direct protection from violence. Defection during the mid-forties, for example, might be costly in terms of lost fitness relative to potential gains from starting a new union. This is especially true if opportunity costs decline with age owing to his decreasing mate value and expected productive lifespan. ${ }^{2}$

The next section describes seven predictions consistent with the theoretical perspective outlined above, applied to an ethnographic test case among the Tsimane in the Bolivian Amazon.

\section{Predictions}

P1: Marital preferences (related to "threat points") should include economic productivity or "work effort" for both sexes; this contrasts with a popular view that women primarily value income, resources, and/or social status in longterm partners whereas men primarily value physical attractiveness and fertility. While men may weigh physical features higher than do women, both sexes should rank criteria concerning productivity highly.

P2: Labor contributions within marital unions should be complementary. Given a long learning curve for many activities, an efficient division of labor within a household that pools its resources should not have its adult members engage in the same activities. A stronger test of task complementarity should additionally show that $(a)$ men specialize in those tasks that are strength-intensive and that compete with childcare, $(b)$ women specialize in tasks more compatible with childcare, and $(c)$ tasks requiring substantial on-the-job learning should show sex-specific specialization.

\footnotetext{
${ }^{2}$ Attractiveness, status, wealth, specialized skills or abilities, productivity, motivation, and other potential bargaining chips can vary among men and during their lifetimes. Attractive men with "good genes" might invest less in children than less-attractive men who need to compensate with more long-term investment (Waynforth 2001). High-status Aka men spend less time with their children than lower-status men (Hewlett 1992). The opportunity cost of men's time spent in subsistence tasks should also be affected by the ease of encountering and wooing other potential mates given the number of male competitors, payoffs to building and maintaining coalitions with other men and affinal kin, difficulty and productivity of different foraging activities and the social currency of different foods, and availability of leisure activities.
} 
P3: At equilibrium, high producers should be assortatively paired. An efficient and productive household requires active men and women. If work effort and productivity are important mate choice criteria, a system of mutual mate choice should result in similar levels of work between spouses, even though the categories of work being done by each partner may be different.

P4: There should be higher reproductive gains among marital unions with higher contributions to "public" household production, including childcare and food production. Since Tsimane do not practice efficient birth control, any increase in household production should be reflected in higher fertility and offspring survivorship. Higher fertility may also motivate greater household production, but this study lacks the longitudinal design to confidently assess the direction of causality. Instead, we add spousal ages as controls that independently predict fertility.

P5: Hunters' higher social status should be linked to gains within marital unions and not just private gains (i.e. extra-pair copulations). We posit that men's specialization in hunting is a coordinated outcome meant primarily to complement women's activities in a sexual division of labor, rather than advertise phenotypic quality to non-mates. Therefore, better hunters should show higher fitness gains within rather than outside of marital unions. Additionally, the gains of social status (accruing from hunting reputation) may include household benefits, such as childcare, coalitional support, health insurance - all of which can improve the survivorship of household members.

P6: Relative bargaining power between spouses matters for leverage (i.e., getting away with doing less). Even though we expect positive assortment based on work effort (P3), those with more bargaining power may do less in-pair productive work if more time spent invested in other activities provides greater private gain, and if one's spouse is unlikely to defect or reduce investment in the household. We recognize that our ability to test this prediction is limited owing to the endogeneity in our post-hoc bargaining power measure. Bargaining power is often difficult to measure in a way that is independent of observed characteristics that influence behavior, or that are not themselves outcomes, rather than determinants, of the bargaining process. Relative bargaining power is here crudely operationalized as relative mate value and measured in two different ways in two villages (see "Methods"). Mate value is considered relative to one's spouse, and also relative to other same-sex individuals in the community. Since our bargaining power measure is not independent of our dependent variable — work effort — our analysis here is exploratory.

P7: The dynamics of work effort allocation may change over the course of a marriage if relative mate value of partners changes over time. One simple prediction is that if female reproductive value declines more rapidly over the course of a marriage than male reproductive value, men's relative mate value becomes increasingly higher and husbands should be more inclined to seek out extra-pair matings and other forms of private gain (Winking et al. 2007). However, as number and overall dependency of offspring increase over time, men will also have more invested in the marital relationship, and opportunity costs for activities imparting private gain may be prohibitive. 


\section{Study Population}

Roughly 9,000 Tsimane forager-horticulturalists inhabit more than 60 villages along the Maniqui River and associated tributaries in the Beni Department, Bolivia. Kin-related families live in close proximity, forming well-defined household clusters. Tsimane derive the majority of their calories from family-maintained fields consisting mainly of rice, plantains, corn, and sweet manioc. Agricultural food is subsidized with wild game, fish, foraged fruits, and some market goods (depending heavily on proximity to local markets). General ethnographic information is given in Chicchón (1992) and ReyesGarcía (2001).

Tsimane do not commemorate weddings with formal ceremonies but consider a pair to be married when they sleep together in the same house. Cross-cousins are preferred marriage partners, but distant relatives are often selected. Men often leave their natal villages to seek mates during social visits, foraging excursions, village festivals, and trips to town. Parents or other relatives may also aid in marrying their sons or daughters. Suitors usually ask a woman's parents for permission to marry, although abductions and forced marriages are not uncommon (Table 1). There is no formal gift exchange at marriage, although informal bride service is common. Polygyny is widely accepted except in the two villages with an active missionary presence. Overall, only $5-10 \%$ of men are polygynously married, almost always to two sisters. Marriages are stable among the Tsimane, with less than $20 \%$ of marriages ending in divorce ( 15 of 76 marriages begun $>20$ years ago). Divorce is most common in the first year of marriage. Postmarital residence patterns tend to be matrilocal until the first child is born, followed by patrilocal residence. However, there is much flexibility in this pattern.

Nuclear families are typically the unit of production, particularly for garden foods. Consumption occurs within extended family units living in close proximity to each other. Family members may coordinate work activities in the early morning, especially if one member intends to make a trip to a distant field or to a fishing location by canoe. Hunts are often planned the day before, although the final decision to hunt may depend on climate, physical state of the hunter, and whether or not the hunter had an ominous dream during the previous night.

\section{Methods}

Many of the ethnographic methods employed to test the seven predictions presented above have been described elsewhere (Gurven et al. 2007; Gurven and Winking 2008; Rucas et al. 2006; von Rueden et al. 2008; Winking et al. 2007) and so are only briefly summarized here.

Economic productivity is operationalized as time spent engaged in work-related activities. Time data exist for five villages totaling 28,347 time points. These data are based on spot observations of household residential clusters during 2-hour and 3-hour observation blocks. During these blocks, all activities of members from several families were recorded every half hour. Percentage of time individual $i$ spent in activity $j$ is the percentage of all of $i$ 's person-scans during which he or she was engaged in $j$. Work activities are grouped into direct and indirect production. Direct 
Table 1 Mating Preferences based on (A) actual marriages and (B-E) hypothetical scenarios. In A, “\% of times listed" refers to the percentage of all cases where men (or women) listed a preference category (e.g., good character) in a spouse. For B-E, "Avg. Rank" is the average rank for each preference (from 1 to the number of options for each question: 13 for B, 18 for C, and 16 for D and E), averaged over all women's responses

\begin{tabular}{|c|c|c|c|c|}
\hline Question & $\begin{array}{l}\text { Men's Preference } \\
(n=107 \text { men })\end{array}$ & $\begin{array}{l}\text { \% of times } \\
\text { listed }\end{array}$ & $\begin{array}{l}\text { Women's Preference } \\
(n=117 \text { women })\end{array}$ & $\begin{array}{l}\% \text { of times } \\
\text { listed }\end{array}$ \\
\hline \multirow{7}{*}{$\begin{array}{l}\text { (A) "Why did you marry } \\
\text { this person?" }\end{array}$} & Wanted to & 27.1 & Against will & 37.6 \\
\hline & Good Character & 21.5 & Good character & 17.1 \\
\hline & Food/drink/helpful & 19.6 & Food production & 15.4 \\
\hline & Appearance & 15.0 & Wanted to & 14.5 \\
\hline & No other options & 14.0 & Kin arranged & 9.4 \\
\hline & Against will & 11.2 & No other options & 6.8 \\
\hline & & & $\begin{array}{l}\text { Women's Ranked } \\
\text { Preference }(n=56)\end{array}$ & Avg. Rank \\
\hline \multirow{5}{*}{$\begin{array}{l}\text { (B) "What are traits } \\
\text { of a good father?" } \\
N \text { options }=13\end{array}$} & & & Cares for his children & 4.1 \\
\hline & & & Farming & 5.2 \\
\hline & & & Fishing & 5.6 \\
\hline & & & Hunting & 5.8 \\
\hline & & & Access to town & 6.1 \\
\hline \multirow{5}{*}{$\begin{array}{l}\text { (C) "What are traits } \\
\text { of a good mother?" } \\
N \text { options }=18\end{array}$} & & & Loves her children & 6.0 \\
\hline & & & Clean house & 6.6 \\
\hline & & & Clean clothes & 6.8 \\
\hline & & & Good breastmilk & 7.6 \\
\hline & & & Fishing & 6.0 \\
\hline \multirow{5}{*}{$\begin{array}{l}\text { (D) "What are important } \\
\text { traits in a man to } \\
\text { marry your daughter?" } \\
N \text { options }=16\end{array}$} & & & Wants only your daughter & 5.2 \\
\hline & & & Handsome/young & 6.1 \\
\hline & & & Wants many children & 6.4 \\
\hline & & & Access to town & 6.4 \\
\hline & & & Physically strong & 7.0 \\
\hline \multirow{5}{*}{$\begin{array}{l}\text { (E) "What are important } \\
\text { traits in a man you } \\
\text { would marry?" } \\
N \text { options }=16\end{array}$} & & & Speaks Spanish & 5.5 \\
\hline & & & Handsome & 5.5 \\
\hline & & & Wants only you & 6.9 \\
\hline & & & Fishing & 7.1 \\
\hline & & & Wants many children & 7.1 \\
\hline
\end{tabular}

production includes hunting, fishing, farming, collecting, and wage labor. Direct "food" production excludes wage labor. Indirect production includes food processing, cooking, getting water and other materials, washing and repairing clothes, manufacture, and childcare. 
Mate preferences were investigated in two samples. The first comes from demographic interviews in fifteen villages of 224 adults over age 18. Participants were asked: "Why did you marry this person?" This was an open-ended question concerning the traits found desirable in their current or past marriage partner. Seven categories were created based on responses: Active desire, Good character, Food production, Physical appearance, Had no other options, Against will, and Arranged. Each individual's responses were scored as one or zero for the presence or absence of each category. The second sample of 117 women from two villages (Ton'tumsi and Moisisjac) focused on the desirable qualities of a good father, mother, man to marry (if unmarried), and man to marry your daughter (for women already married). Women were instructed to rank a series of fixed traits depicted in staged photos that were designed to better facilitate understanding of the ranking procedure. Traits included: Cares for children, Handsome, Good hunter, Productive farmer, Has access to market town, Loves children, Wants many children, Speaks Spanish, among others. For each question and trait, mean ranks were calculated by averaging the ranks for each trait among all same-sex interviewees.

Mate value was measured differently in two villages. In Micdyiĉa, men were instructed to imagine that they were single, that every woman in the community was an eligible partner, and to rate on a five-point scale the extent to which they thought each woman in the community would make a good spouse. The same was done by women for men. In Ton'tumsi, the post-hoc measure of mate value differs by sex. Female mate value was assessed as ratings of the physical attractiveness of other men's wives by a group of resident men. Male mate value was based on other men's evaluations of four characteristics related to social status: winning a physical confrontation with another man, getting one's way in a group conflict, community influence, and respect. We average the rankings of the four measures to create a single status measure for men.

\section{Results}

\section{P1. Do marital preferences include work effort and/or productivity for both sexes?}

Table 1 lists commonly reported desired mate characteristics. With respect to actual mates, good character and food production were two of the top three categories mentioned by both men and women (Table 1A). Good character refers to kindness, generosity, and strong work ethic, but also includes "makes me laugh." Production, as mentioned by women, referred to men's ability to produce food, particularly meat, fish, and rice. For men, productivity among women referred to traditional beer brewing from sweet manioc, and responsibility in childcare. Despite the preferences stated above, almost half of women's marriages were arranged by kin or were a result of husbands forcing women to marry them. Arranged marriages usually occur soon after a girl has had her first menses; despite a voiced unwillingness to marry, however, few of these marriages end in divorce.

In the second sample invoking women's hypothetical preferences, aspects of economic productivity consistently appear in the five highest-ranked traits that characterize a good father, mother, and husband (Table 1B-E). Good fathers should 
care for children and be proficient farmers, hunters, and fishermen. Good mothers should love their children (i.e., be attentive to their needs), keep a clean house, and ensure that familial clothes are clean. Tsimane women also report that having an adequate supply of healthy breastmilk is important; not only do women sometimes complain about not being able to feed babies sufficiently (interbirth intervals are rather short, at 2 years on average), but women believe that healthy, strong milk is necessary for proper child growth and development. A good mother also provides fish as a supplement to the diet through hook-and-line fishing in acculturated villages where husbands may be absent owing to wage labor opportunities. Commitment to the spouse and desire for a large family are two important traits in a husband. Finally, being handsome and young are largely unrelated to household production but are nonetheless important traits in a husband.

\section{P2. Are labor contributions complementary?}

The Appendix lists 90 activities comprising nine categories of direct and indirect production. Of those $90,22 \%$ are almost exclusively male activities (defined here as men participating in $\geq 85 \%$ of spot observations) and $27 \%$ are almost exclusively female activities. Half of all work activities are thus highly segregated by sex. These account for $46 \%$ and $49 \%$ of men's and women's work time, respectively. In only $11 \%$ of activities (accounting for $16 \%$ of men's and 17\% of women's work time), men and women were roughly equal participants (40-60\% of spot observations). Men specialize in hunting, wage labor, heavy farming labor (clearing, chopping trees, weeding), and bow-and-arrow and net fishing. Women specialize in cooking, food preparation, childcare, and domestic tasks. Figure 2 illustrates the complementarity - men engage more in direct acquisition and women in indirect production, but summed together men and women spend roughly equal time in production: men spend an average of $4.8 \mathrm{~h}$ per day engaged in work activities and women, 5.3.

Figure 2 also highlights changes in labor patterns as a function of age. Wage labor peaks among men in their twenties, hunting peaks in the thirties and forties, and garden labor peaks among men older than fifty. Much of direct parenting is done by women in their prime reproductive years, whereas older women consistently spend more time processing food. Direct productive tasks among women and indirect labor tasks among men remain relatively consistent over the lifespan.

We test whether men specialize in strength-intensive tasks that are incompatible with childcare activities, and whether tasks requiring substantial on-the-job learning are more likely to show sex-specific specialization. We define specialization as $\geq 85 \%$ of time points for an activity pertaining to only one sex. Each of the 90 activities was independently scored by MG, JW, and a third experienced fieldworker, Amanda Veile, as low (1), medium (2), or high (3) for strength requirements, skill requirements, and incompatibility with childcare. Cronbach's $\alpha$ was sufficiently high $(0.886,0.830$, and 0.894 for the three respective measures), so we use average rankings among the three scorers and recategorize low as $1-1.66$, medium as $1.67-2.33$, and high as 2.34-3.00. Men overwhelmingly specialize in activities that are high strength $(67 \%$ of men's 18 specialist activities), high skill level (61\%), and highly incompatible with childcare $(83 \%)$. We find that women specialize in activities that are low strength $(96 \%$ of women's 23 specialist activities), low skill level (78\%), and most compatible with childcare $(100 \%)$. Because high-skill activities tend to be high strength (Spearman rank 
Male

a. Labor outside the household

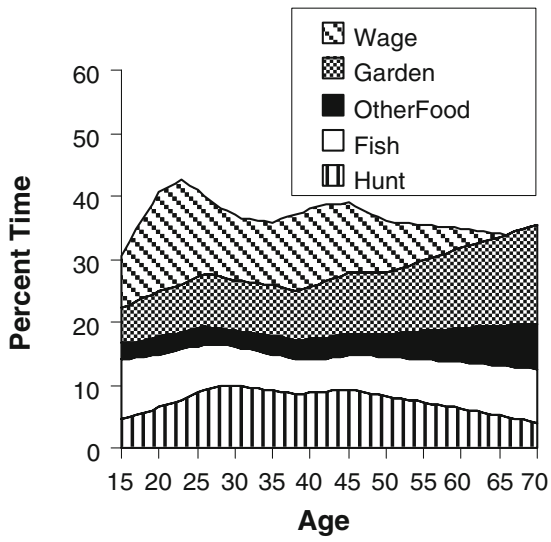

b. Household labor

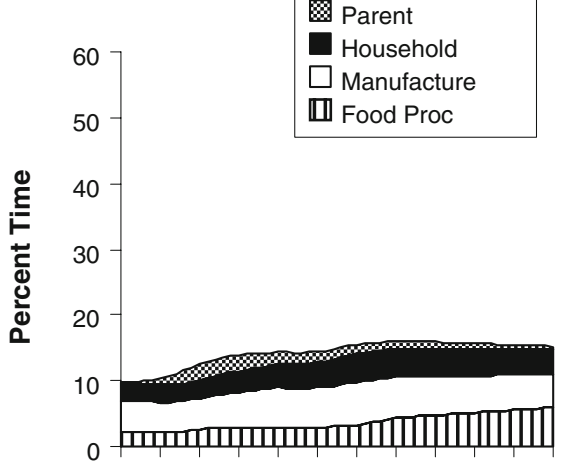

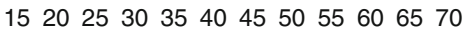

Age
Female
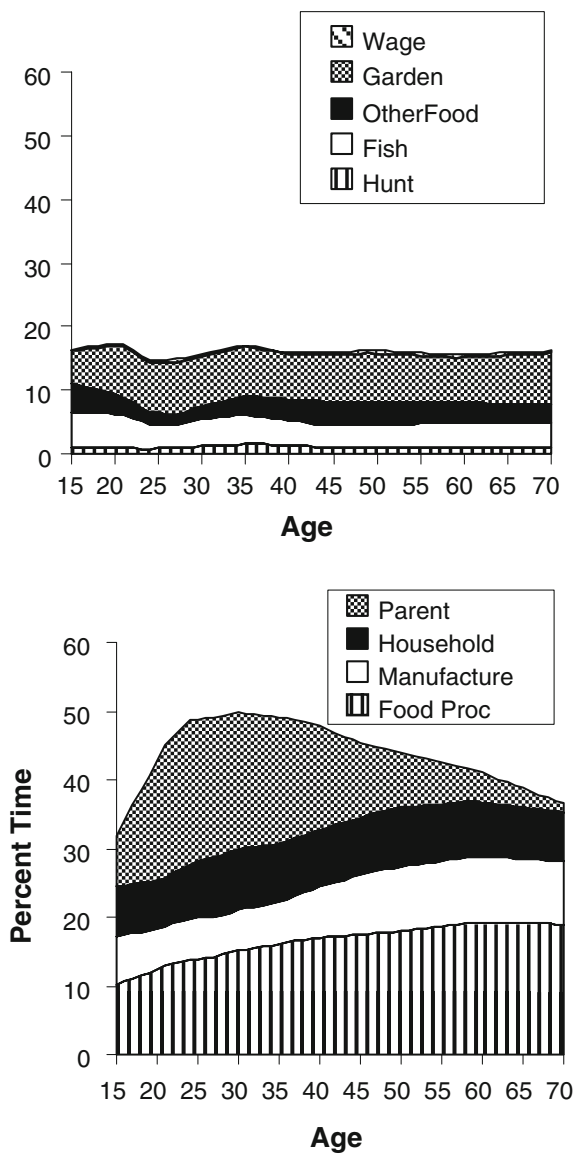

Fig. 2 Percentage of time men and women spend in (a) productive labor outside the household and (b) domestic labor inside the household

correlation $r=0.584, p<0.0001)$ and incompatible with childcare $(r=0.657$, $p<0.0001$ ), we ran a multiple regression examining the simultaneous impact of each of the three activity factors (fixed effects) on the percentage of scans where that activity was performed by a male (Adjusted $R^{2}=0.68, \mathrm{df}=6, \mathrm{~F}=64.16, p<0.0001$ ). Childcare incompatibility had the strongest predictive effect, with high incompatibility activities showing an additional $47 \%(p<0.0001)$ more male participation than low incompatibility activities. High-skill activities showed an additional $21 \%(p<0.001)$ more male participation than low-skill activities. Strength, however, was insignificant when the other two factors were controlled.

\section{P3. Are high producers assortatively matched?}

Men who spend more time in production are married to women who do the same (Fig. 3). Although this relationship is highly significant, men's production time 


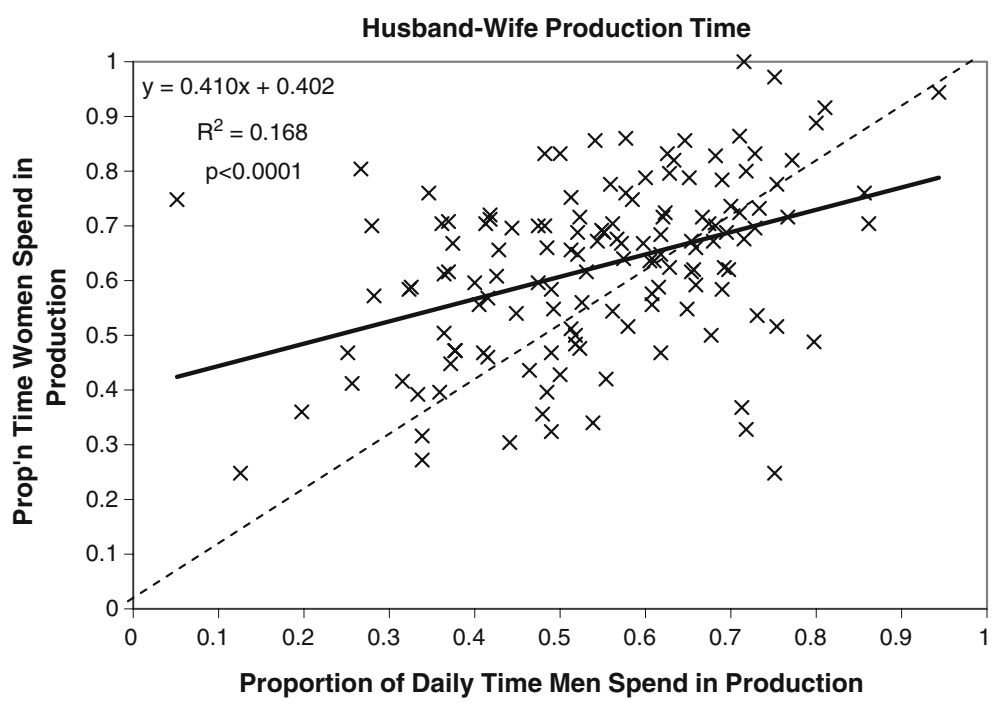

Fig. 3 Relationship between the proportion of daily time spent in total production among husbands and wives. $N=138$ husband-wife pairs from five communities (Micdyiĉa, Cuverene, Aperecito, Ton'tumsi, Jamanchi). The dashed line defines equal production time by husbands and wives

explains only $17 \%$ of the variation in women's work time. The slope of the relationship between time men and women spend in daily production is less than unity (0.41) and has a positive $y$-intercept, which indicates that men who spend less than two-thirds of their time in productive tasks are paired with wives who spend more time in production than they do, whereas men who spend more than two-thirds are paired with less-productive wives. A similar relationship of the same magnitude is found for the relationship between husband's and wife's direct and indirect production time. Overall, women spend more time working than their husbands in $66 \%$ of husband-wife pairs. If we restrict analysis to those dyads where the difference between the husband's and wife's production times is greater than 5\% (i.e., $36 \mathrm{~min}$ ), women still spend more time working than their husbands in $56 \%$ of the dyads, men more than wives in $18 \%$, and both spend roughly similar time in the remaining $26 \%$.

Alternative explanations may account for the correlation between husbands' and wives' work times. First, spouses may both be adjusting their work effort according to the number of dependent children they have as they get older. However, controlling for ages of husband and wife, and for number of surviving children, had no effect on the magnitude or statistical significance of the correlations between the husband's and wife's work times. Thus, spouses are assortatively matched for work effort not just because partners in any dyad have the same number of children.

Another possibility is that the spousal work time correlation is the result of the bargaining process occurring during the marriage and may not reflect assortative mating prior to marriage. Although this possibility is difficult to test given our data, it is worthy to note that individuals of high mate value are also assortatively matched, based on analyses using both measures of mate value (Micdyiĉa, $\beta=0.74$, std. $\beta=0.58, p=0.0023$; Ton'tumsi, $\beta=0.41$, std. $\beta=0.25, p=0.093$ ). The relationship is stronger in Micdyica, where the mate value measure was identical for both sexes and the measure included 
any aspect of desirability, rather than focusing on only certain traits, as was done in Ton'tumsi. Controlling for husband's and wife's age and number of dependent offspring does not change the magnitude or strength of the relationship.

\section{P4. Do high-producing couples have higher fertility?}

For simplicity, we restrict analysis to monogamous couples who did not have former marital partners. This reduces the sample from 138 couples to 120. After controlling for husband's and wife's age (which will independently predict fertility), the amount of time a husband or wife spent engaged in work labor was positively associated with the total number of the wife's live births and with the number of offspring that survived to age 5 (Table 2). The combined total time spent working is also significant, showing a higher standardized parameter estimate than work time of either spouse alone. Each additional hour spent working is associated with about 0.3 more births and 0.2 more surviving offspring.

Further analysis reveals that husband's and wife's direct production times significantly correlate with fertility whereas indirect production does not. Only husband's direct production predicts total number of surviving offspring. When we focus on subcategories of direct and indirect production, three subcategories - men's and women's fishing, and women's childcare - are positively associated with fertility (standardized $\beta$ in controlled regression: 0.093, 0.093, 0.165, respectively). Men's wage labor time and women's childcare time both positively associate with number of surviving offspring $(\beta=0.123$, 0.109 , respectively). However, a husband's time spent food processing was found to negatively associate with number of offspring survivors $(\beta=-0.136)$.

Although these analyses show trends consistent with the prediction that high producers generate high fertility, it is plausible and expected that families with more children will need to spend more time working. This is particularly true with regard to time spent in childcare. For example, Hadza men increased food production while their wives spent less time producing food and more in childcare when wives had small children (Marlowe 2003). Parents with many children could also work more intensively or efficiently, a prospect beyond the scope of the analysis presented here. Only a longitudinal study could confirm that prior commitment to high levels of coordinated work effort between spouses results in higher subsequent fertility.

Table 2 Regressions of reproductive performance (a: total fertility and b: number of offspring surviving to age 5) as a function of work time, done separately for husband's and wife's and then for combined husband's and wife's work time. Each row refers to a multiple regression that controls for husband's and wife's ages.

\begin{tabular}{lcccccr}
\hline & $\beta$ & std. $\beta$ & SE & $t$ & $p$ & $R^{2}$ \\
\hline $\begin{array}{l}\text { A. Total fertility } \\
\text { Husband's total work time }\end{array}$ & 0.225 & 0.117 & 0.101 & 2.24 & 0.027 & 0.691 \\
Wife's total work time & 0.277 & 0.141 & 0.102 & 2.70 & 0.008 & 0.697 \\
Total work time & 0.174 & 0.152 & 0.059 & 2.94 & 0.004 & 0.700 \\
B. No. of offspring surviving to age 5 & & & & & 0.023 & 0.699 \\
Husband's total work time & 0.194 & 0.118 & 0.084 & 2.30 & 0.023 & 0.691 \\
Wife's total work time & 0.128 & 0.077 & 0.088 & 1.46 & 0.147 & 0.698 \\
Total work time & 0.113 & 0.116 & 0.051 & 2.23 & 0.028 & \\
\hline
\end{tabular}


Nonetheless, we failed to falsify the prediction at this first stage; we found that productive men are paired with productive women, and that higher work time among both partners associates with higher fertility, even after controlling for husband's and wife's ages. Regardless of the cause-and-effect relationship, and despite the fact that current work conditions may not reflect commitments to household investment prior to marriage, work effort should remain high among high-fertility households as long as offspring demand requires it.

P5. Do better hunters have higher in-pair gains, or are the benefits they receive external to the marital union?

Results from a recent paper are presented here (Gurven and von Rueden 2006). Controlling for men's age, we found that in a sample of 57 men from Ton'tumsi, good hunters achieve higher social status. They were rated by other men as worthy of respect (partial $r=0.457, p<0.001$ ), influential members of the community (partial $r=0.293, \mathrm{p}=0.029$ ), and likely to receive more coalitional support during a conflict (partial $r=0.248, p=0.065$ ). Good hunters have higher in-pair fertility, in terms of both total offspring (partial $r=0.469, p<0.001$ ) and offspring surviving to age 15 (partial $r=0.379, p=0.004$ ). The difference between hunters in the top and bottom deciles is 2.8 total births and 2.3 surviving offspring. Better hunters are also more likely to have wives rated as more attractive by other men (partial $r=0.390, p=$ 0.009). In two remote Tsimane villages, where polygyny is more common, more productive hunters have more wives (partial $r=0.359, p=0.009$ ) and are more likely to marry earlier (mean difference $=0.5$ years, loglikelihood test, $\chi^{2}=3.19, p=0.074$ ).

In Ton'tumsi, good hunters were more likely to be ranked as "meat sharers" and as "hard workers." Hard workers also have a greater number of in-pair live births (partial $r=0.386, p=0.003$ ) and surviving children (partial $r=0.274, p=0.045$ ). Generous sharers of meat are more likely to receive coalitional support in the event of a conflict (partial $r=0.334, p=0.012$ ), have wives rated as more attractive by other men (partial $r=0.342, p=0.016$ ), and produce more total (partial $r=0.280, p=0.040$ ) and surviving (partial $r=0.254, p=0.064$ ) offspring. When we control for both hunting ability and age, however, meat sharing is no longer associated with higher inpair fertility, whether measured by total (partial $r=0.186, p=0.183$ ) or surviving (partial $r=0.164, p=0.240$ ) offspring. Controlling for meat sharing and age, hunting ability remains a strong predictor of both total (partial $r=0.338, p=0.013$ ) and surviving (partial $r=0.310, p=0.024$ ) offspring.

Neither hunting ability (partial $r=0.185, p=0.173$ ) nor meat sharing (partial $r=0.116$, $p=0.394$ ) bore a significant relationship with extra-pair mating when controlling for age.

\section{P6. Relative mate value should predict labor discrepancies among husband-wife dyads.}

Mate value can be assessed relative to same-sex individuals and relative to one's marital partner. Relative work effort can be assessed in a similar manner. Table 3 gives the results of regression analyses that examine the effect of a partner's relative mate value on work effort patterns. All analyses control for husband's or wife's age and are shown separately for Ton'tumsi and Micdyiĉa because of the different methodologies used to measure mate value in each village. Alternative specifications that control for completed fertility or number of consumers (those younger than 


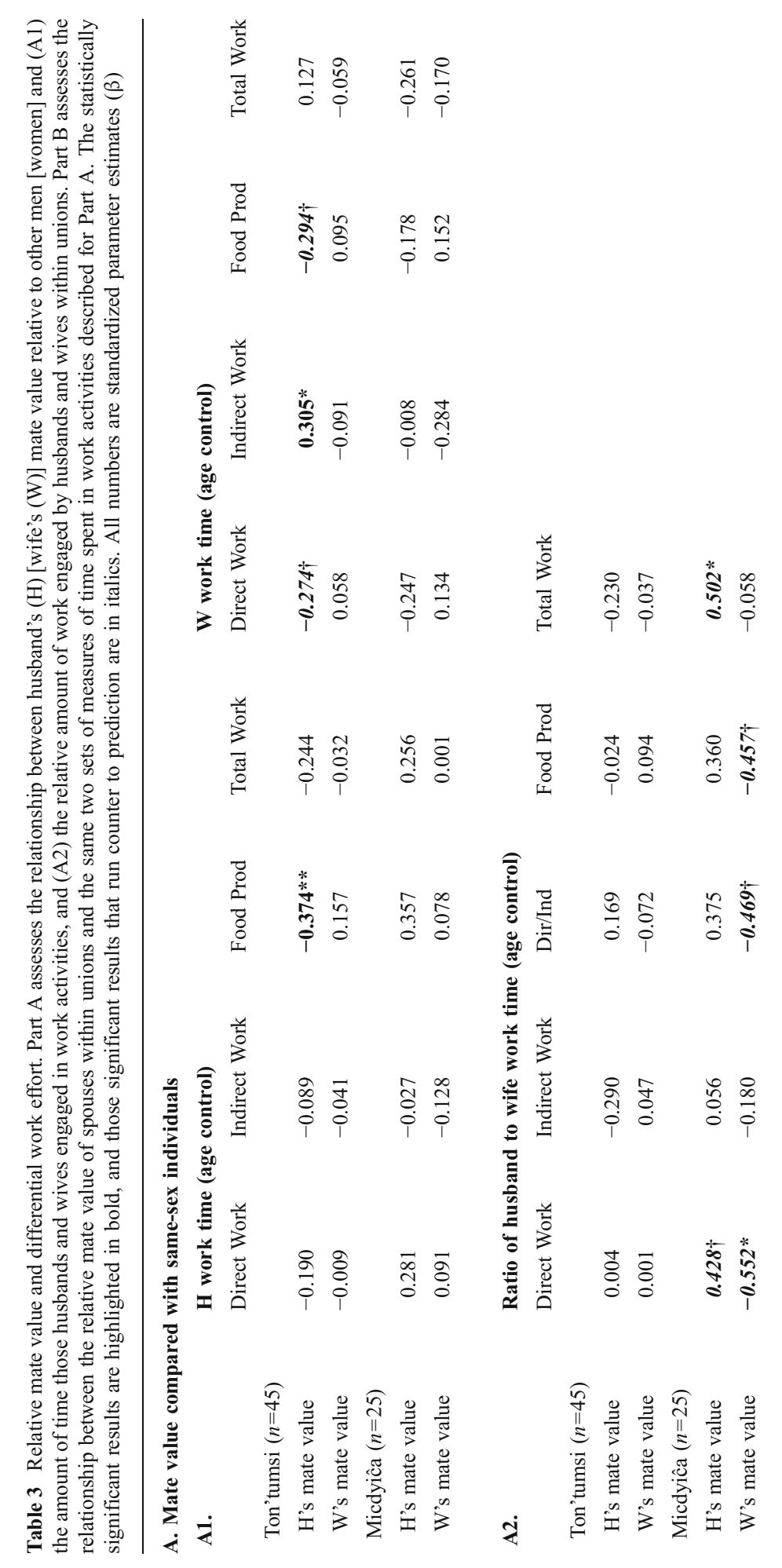




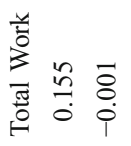

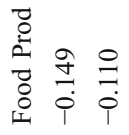

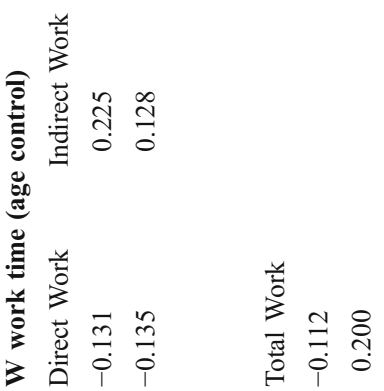

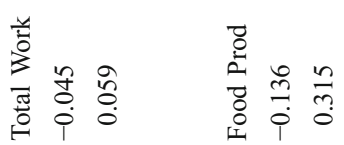

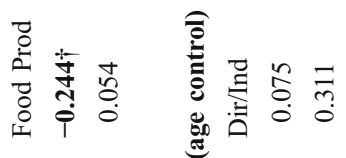

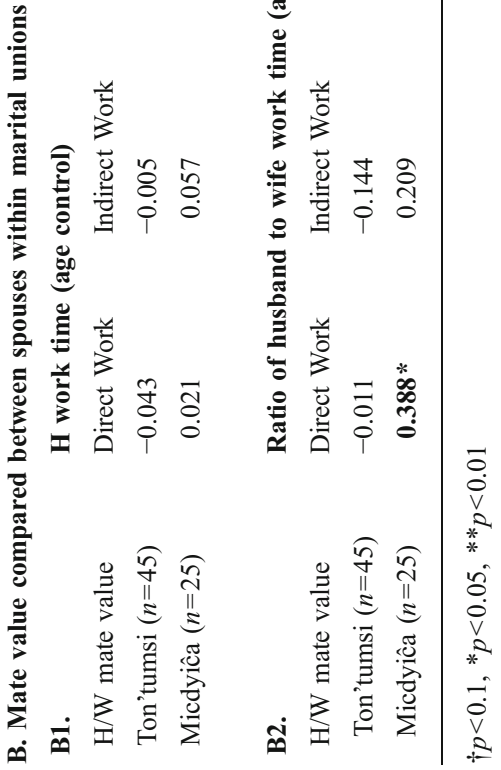


16 years old) in the household yield the same results. Of the eleven statistically significant results presented in Table 3, only three are consistent with the notion that having higher mate value (whether relative to same-sex competitors or to spouse) should associate with spending less time engaged in work activities: Husbands from Tom'tumsi with higher mate value than other men spend less time engaged in direct food production than other men (std. estimate $\beta=-0.374, p<0.01$ ), while their wives spend more time engaged in indirect work $(\beta=0.305, p<0.05)$. Further analysis reveals that these men engage less in garden labor $(\beta=-0.460, p<0.01)$ and food processing $(\beta=-0.201, p<0.1)$, but more in wage labor $(\beta=0.269, p<0.1)$, while their wives are more likely to engage in parenting $(\beta=0.447, p<0.01)$. Husbands from the same community who rank higher relative to their mates are also less likely to engage in overall food production than other men $(\beta=-0.244, p<0.1)$.

Most of the significant results inconsistent with our predictions come from Micdyiĉa, where mate value was all-inclusive. Those results suggest that men of higher mate value are more likely to contribute labor time to direct work (hunting, gardening). Men of high mate value, however, do engage less in parenting activities $(\beta=-0.381, p<0.1)$. Husbands engage in more direct work, and more total work overall, than their spouse, the higher their mate value relative to other men's. A wife tends to spend more time in food production, and work overall, the higher her mate value relative to other women's. These results, which seem inconsistent with the leverage hypothesis, are likely due to the mate value measures not being independent of work effort. Work effort is an important trait for marriage (Table 1) and was therefore probably a salient consideration in evaluations of men's and women's mate value in Micdyiĉa. Thus, many of the analyses in Table 3 show that a person's higher mate value means they work more, not less, than we might expect according to the leverage hypothesis. Other measures of bargaining power or leverage would be desirable. Our results are therefore more inconclusive rather than showing strong evidence against the leverage hypothesis.

\section{P7. As relative mate value changes over the course of a marriage, does the likelihood of male defection increase?}

Although no longitudinal data on activity budgets yet exist to confidently answer this question, a recent paper examined the timing of extramarital affairs by Tsimane men in two less-acculturated communities (Winking et al. 2007). Tsimane men were more likely to engage in extramarital liaisons early in a marriage when offspring dependency was low, rather than later in a marriage when their wives' reproductive value was low. One-fourth of men were likely to engage in affairs in the first year of marriage, and not until 10 years into a marriage did the proportion of men having affairs drop below 5\%, where it remained thereafter at this low rate (Fig. 4). Frequency of affairs was negatively associated with number of dependents and age of the man, even after controlling for the wife's age and duration of marriage.

In the more acculturated community of Ton'tumsi, men's extramarital affairs are positively correlated with the number of dependents $(r=0.260, p=0.051)$, but this effect disappears when controlling for men's mate value (partial $r=0.051, p=0.711$ ). Compared with men in Micdyiĉa, men in Ton'tumsi on average experience greater access to material wealth through wage labor, a principal source of social status in this community (von Rueden et al. 2008). 


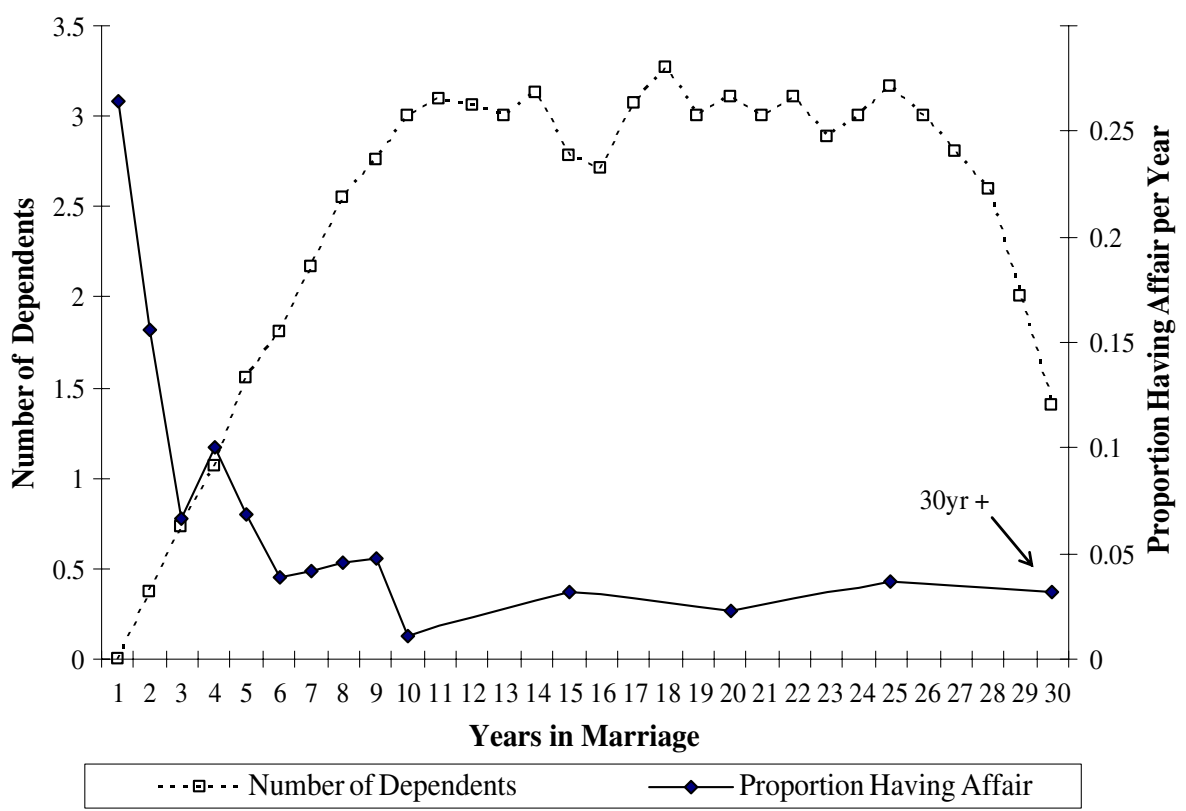

Fig. 4 Extramarital affairs and number of dependent offspring. (Reproduced with permission from Winking et al. 2007)

\section{Discussion}

A combined evolutionary and microeconomic perspective on family formation and household work effort can help explain variation in marriage patterns and sexual divisions of labor. When different tasks require substantial on-the-job learning and the labor of different "specialists" is not easily substitutable, a sexual division of labor can be a desirable enterprise because it results in comparative advantage, interdependence, and economies of scale in total production. Although interdependence may require spouses to cooperate for the production and maintenance of children, divisions of labor need not be highly coordinated and efficient, and conflicts of interest are expected based on differential private gain from non-marital pursuits.

We have shown that important criteria for long-term partners include notions of work effort and productivity for both sexes. Productive Tsimane men are paired with productive women, and these pairs show higher in-pair fertility and their children show higher survivorship.

These results are consistent with studies in modern urban societies showing positive assortment among mates on a variety of related characteristics, such as socioeconomic status, cognitive abilities, values, interests, attitudes, and personality dispositions (Buss and Barnes 1986; Schoen and Cheng 2006; Schwartz and Mare 2005). These findings support the notion that both husbands and wives benefit from each other's labor and that marital partners have incentives to optimize joint productivity. Greater investments in indirect production, however, were not associated with higher fertility; it is possible that time may be too crude a measure of investment in work effort because it ignores the efficiency of actors during work 
tasks. However, another likely possibility is that the marginal cost of additional children on time spent in indirect production may be small for many types of nondepreciable or umbrella care, such as babysitting and passive childcare.

We also reported that in the unacculturated villages, men's extramarital affairs were concentrated in the early years of marriage, and not later when wives have lower reproductive value. Even if women with children were less likely to divorce their husbands after discovery of infidelity, owing to higher transaction costs in finding a new partner and potentially lower mate value in the mating market (Arendell 1986), we found no evidence that infidelity increases during the course of Tsimane marriages in unacculturated villages. This result contradicts the view that men's investment in children is a by-product of mating effort decisions (whether targeted at in-pair or extra-pair mates) and instead is more consistent with the view that men's contributions represent genuine parental effort, despite occasional extramarital benefits that accrue to generous producers.

In the acculturated village, however, men's extramarital affairs were not concentrated early in the marriage but were closely tied to wage labor and material wealth acquisition. The fact that in-pair fertility was also higher among wealthier men suggests that these husbands are able to effectively allocate budget surpluses to both private and household pursuits. Furthermore, men in acculturated villages might have more opportunity to pursue extramarital relationships owing to the greater divisibility and liquidity of wages and the lower risks of detection: many of the reported affairs in Ton'tumsi occurred on logging excursions in other villages.

The generality of these findings in other societies has not been established. For instance, Winking et al. (2007) argue that men continue to invest in the household, rather than divert resources to the pursuit of additional mating opportunities, because of the greater fitness gains from investment in the high number of dependent offspring and grandoffspring characteristic of natural fertility societies. A 50-year-old Tsimane man married to a 46-year-old woman, on average, will have 6.5 children- -0.5 under age 5, and 2.7 under age 15-and just under 8 grandchildren, all of whom are under age 15. In the absence of growing dependency, however, we expect that conflict and marital instability may increase throughout a marriage. The shift in relative mate value between spouses could have a greater impact on behavioral patterns among couples in Western populations who choose not to have children.

It is likely, as well, that men's mate value in the mating market declines at later ages; a man's production declines in his fifties, especially for hunting, and more so in his sixties. His social status, whether measured as ability to win a physical confrontation, get his way in group conflict, his influence, earned respect from others, or the sum of these four traits, also declines at later ages (von Rueden et al. 2008). Thus, benefits of continued household investment may remain high for men with relatively high fertility, while lower opportunity costs may also favor continued household investment and less infidelity. However, some high-status men may be able to support two wives or successfully pursue additional mates when their spouse's mate value declines, as we found in Ton'tumsi, but these are likely to be the exceptions rather than the rule in relatively egalitarian societies where men typically do not accumulate material wealth. Socially imposed monogamy is therefore the dominant marriage pattern among hunter-gatherers (Marlowe 2004; Murdock 1967). Infidelity by high-status men (or women) may be tolerated to the extent that the amount of the man's (woman's) time 
and resources invested in the household is higher than what a wife (husband) could gain elsewhere, especially given transaction costs of finding a new mate.

We applied our theoretical approach only to the Tsimane-a traditional foragerfarmer population with relatively stable, monogamous marriages for most individuals and sororal polygyny for $<10 \%$ of men. The sexual division of labor among Tsimane is moderately high, with about half of all labor activities and roughly half of men's and women's work time spent in tasks that are almost exclusively sex-specific. Similarly, 24 of the 50 "technological activities" documented among 185 ethnographic societies in the Ethnographic Atlas show almost exclusive participation by one sex (where index of male participation is $\geq 85 \%$ or $\leq 15 \%$; Murdock and Provost 1973: Table 1).

The utility of our approach depends on whether it can help explain marital arrangements and labor divisions in other types of societies. Our approach does not uniquely predict which tasks should be performed by which sex, nor the extent of women's coordination with men other than biological fathers, but it does suggest which types of tasks are more likely to show sex-specific specialization (P2). The framework is general; wider applicability to a broad range of societies requires information on $(a)$ the set of economic activities and technologies necessary to implement them (particularly skill and strength requirements, and compatibility with childcare; Gurven and Kaplan 2006); (b) exchange and signal value of different products (e.g., meat vs. plantains); (c) factors impacting value of household investments, such as women's fertility, paternity certainty (Gaulin and Schlegel 1980), and fitness payoffs to different types of paternal investment (Pennington and Harpending 1988); and (d) factors impacting value of private investments, including availability of alternative caretakers, and fitness benefits of social visitation and "leisure." Access to fertile women will be affected by the age structure of the population, age gaps in mating partners, and social norms regarding infidelity.

Regardless of the normative arrangements for different societies, the specific amount of spousal household investments should also depend on relative bargaining power of spouses, which itself may be influenced by partner age, abilities, wealth, and attractiveness. These factors can influence the power dynamics that determine relative work effort within couples. ${ }^{3}$ However, we found little consistent evidence that higher mate value, as measured here, correlated with a shift in household labor toward the partner with lower relative mate value, or with lower work effort relative to other same-sex individuals. When men's mate value was alternatively measured as social status, men spent less time in productive labor than did lower-status men, while their wives spent more time in childcare activities. This occurred in an acculturated village where high-status men engaged in wage labor and where greater access to wage labor opportunities and markets likely produced greater variation in men's mate value than in the remote village.

As suspected, our inconsistent findings may be due to the fact that mate value is influenced by the very labor contributions that it is predicted to impact. Although controlled experiments can disentangle the bidirectional causality, anthropologists

\footnotetext{
${ }^{3}$ Leverage can be gained if an individual is capable of performing necessary but difficult tasks, and there are few other surrogates able to fulfill the role. Among the Tsimane, men and women spend comparable amounts of time in garden labor, but women rarely chop down trees during the initial clearing of forest plots. Widowed and divorced women often return to their natal villages and work in their parents' fields, whereas single men can still cultivate their own fields.
} 
cannot experimentally manipulate mate value as do ornithologists (e.g., Zuk et al. 1992). Longitudinal studies, however, exploring substantial changes in relative mate value resulting from the attainment of high-status positions or employment, or changes in physical condition (e.g., illness, obesity), should prove informative. A final approach commonly used by econometricians is the use of instrumental variables to correct parameter estimates when covariates are correlated with the error term in a regression equation because of endogeneity (or omitted variables and measurement error; Pearl 2000).

Prior quantitative studies of the sexual division of labor in non-market societies have largely been cross-cultural in focus, using the Standard Cross-Cultural Sample (e.g., Hendrix and Pearson 1995; Marlowe 2007; Quinlan and Quinlan 2007); these studies take advantage of numerous variables quantified from ethnographies, such as contribution to diet, residence patterns, extent of warfare, female independence, and cultural region. Ethnographic biases aside, those cross-cultural studies focus only on the contributions or aspects of "women" or "men" in general, and rarely on spouses as part of household units. The current study lacks the scope of most cross-cultural studies but instead offers a focused analysis of specific labor patterns of husbands and wives, in relation to the cultural milieu of the Tsimane marriage market. It also examines all forms of labor, rather than focusing exclusively on the direct production of calories.

The overemphasis on direct production is analogous to the traditional focus of employment outside the home in sociological studies of the division of labor in modern societies. Power and influence are often bestowed on high calorie producers and moneymakers, and not butchers window-washers; however, work in production may not be as important as the control of goods (Sanday 1981). Women's role in the distribution of food and other resources should be examined separately from their role in direct production. Although economic independence is certainly an important component of "female power"-the "unnamed, underlying variable in many analyses of divorce rates in sociology and anthropology" (Pearson and Hendrix 1979) - the substitutability of women's activities and the extent of interdependence with husbands may be just as important in the social valuation of women's tasks.

Throughout history it was rare that marriages occurred with full disclosure of partner skills, dispositions, and behavioral tendencies. Given the many constraints on actual mate choice in small, dispersed populations, it may not be surprising that $54 \%$ of Tsimane women and $25 \%$ of men report that they married their spouse because they had no other options or because the marriage was arranged by relatives. Nonetheless, traits related to economic productivity are important, as shown here among the Tsimane. Similar results have been found in all other studies of mate choice criteria conducted in small-scale societies. Among Hadza foragers of Tanzania, both men and women desire strong character and foraging ability (Marlowe 2005). Desirable husbands among the Ache of Paraguay were skilled hunters who "would work hard when everyone was tired" (Hill and Hurtado 1996). Shuar men and women of Ecuador explicitly emphasize resource accrual as important desirable traits in a spouse (Elizabeth Pillsworth, personal communication 2008). The process of declaring expectations and responding to a partner's commitment level can be monitored because of the matrilocal residence and bride service patterns commonly experienced among new couples in forager and foragerhorticultural societies (Collier and Rosaldo 1981). Men must demonstrate their 
willingness to work hard and contribute food to the household under the supervisory gaze of their new spouse and in-laws.

One of the few studies of facultative adjustments in partner behavior (aside from mate removal experiments) was an experimental study of monogamous house sparrows (Schwagmeyer et al. 2002). Contrary to the expectations of biparental care models in which partners adjust facultatively to deviations in their mate's parental effort (Chase 1980; Winkler 1987), the sparrow study showed that both males and females were mostly insensitive to experimental changes in their mate's parental behavior. The authors argue that the "remarkable consistency of each individual's [parental] behavior" is consistent with the notion of "sealed bids," wherein parental effort is instead influenced by individual quality and developmental inputs. Conversely, an observational study of male parental effort among Tsimane (Winking et al. 2009) shows that men preferentially deliver direct childcare when their wives were busy with other tasks or were away from the house, or when other potential babysitters (e.g., older daughters) were absent. That study provides evidence for coordination of activities and suggests that men's investment is not only a signal to his wife.

We hope to encourage more focused studies, especially those that are longitudinal in design. Longitudinal studies would be ideal for examination of changes in work effort by one or both partners after shifts in phenotypic condition that could alter relative mate value and potentially impact costs or benefits of further investing. For example, does sickness, injury, or aging in one partner induce an increase in spousal labor? How does the changing composition of men and women in residential communities impact willingness to invest in the household versus private gain? To what extent do changes in the availability of alternative caretakers impact work effort decisions by each partner? How do longitudinal changes in relative mate value impact labor contributions (besides those universally experienced as a result of aging)?

Even when the conditions described above remain the same, slight changes in one partner's revealed commitment could induce behavioral responses in the other, leading to the proverbial downward spiral toward overt conflict, and the need for readjustment of allocations or perhaps, ultimately, divorce. Domestic strife is expected primarily to result from failure of one partner to meet the expectations of the other, differences in what those expectations should be, differences in perceptions of what constitutes efficient coordination and equitable division of labor, and conflicts regarding unobserved use of time, distribution of household production, and suspected infidelities and paternity (e.g., Gottman 1994). All of these potential sources of tension make sense in the context of a marriage or pair bond that has as one of its implicit goals the coordinated production and reproduction of children.

The dynamics of "negotiation" merit further attention; a partner may threaten to reduce work effort or perform daily tasks poorly as a kind of protest, even if doing so is costly to that partner. Tsimane mothers often blame the sickness and especially the death of newborns on the suspected philanderings of their husbands, and husbands sometimes accuse their wives of being intentionally neglectful of their infants. Such accusations urge spouses to become more committed to household contributions. Consistent with this line of reasoning, postpartum depression has been described as an adaptation to help women negotiate for more social support during a critical time of need (Hagen 1999). Partners may also exaggerate their own contribution while diminishing the value of their spouse's to better optimize their 
own balance of individual and family investments, at the expense of family productivity. Despite their cooperative nature, marriages are expected to contain a mixed level of ambivalence, compromise, and conflict over household contributions.

Finally, our perspective offers a different interpretation of men's foraging efforts and the role of provisioning in human families. It has been actively argued that men's acquisition efforts do not represent true provisioning among hunter-gatherers, and that provisioning cannot account for human pair bonds because meat and other resources acquired by men are unpredictable or unreliable and they are shared widely with nonhousehold members (Bliege Bird 1999; Hawkes 1993; Hawkes and Bliege Bird 2002). Men's participation in hunting or other risky, specialized subsistence tasks cannot be judged independently of women's (or even other men's) coordinated strategies, where members may pool resources together through distribution networks (Jochim 1988). Among Tsimane, good hunters have higher social status, marry at earlier ages, marry women viewed as highly attractive, and are more likely to have more than one wife; their in-pair fertility is also likely to be higher than that of poor hunters. Families of good hunters benefit from a consistent supply of meat, and good hunters have higher mate value in the marriage market. That wives benefit from being in unions, prefer hardworking, more productive men, and are angered by their spouses' infidelities is inconsistent with the view that long-term pair bonding and the division of labor are outcomes of male mating competition. Even when women's roles are confined to "indirect production," women can be dynamic players during the negotiations that occur throughout a marriage; indeed, cross-culturally it is often women who initiate divorce (Quinlan and Quinlan 2007).

\section{Conclusion}

In his classic treatise on the division of labor, Durkheim (1933:200) wrote that groups are more functionally interdependent when there is a sharp division of labor between them. Although he wrote largely about modern, industrial society, he said that the division of labor is "characterized by a cooperation which is automatically produced through the pursuit by each individual of his own interests . . . each individual consecrate[s] himself to a special function in order, by the force of events, to make himself solidary with others." We have shown that a sexual division of labor is efficient, and can be favorable to both husbands and wives, but it is not an "automatic" outcome of self-interested individuals, and it is not always cooperative; the division of labor both separates and binds people together. Following Durkheim's sentiment, the greater interdependence among partners as defined by implicit labor contracts organized under a sexual division of labor may have helped facilitate the formation of (relatively) long-term, cooperative pair bonds among unrelated individuals by decreasing the incentive for one partner to defect on the other. Trust and effective communication are important to coordinate work effort between spouses. However, for pairs, there may be a large set of possible outcomes, the so-called bargaining zone, in which spouses gain or pay costs unequally. Depending on the local socioecology and cultural milieu, a large proportion of marriages may end in divorce and single-parent households. A stable marriage market with relatively fixed pair-bonds and an equitable distribution of costs and/or benefits between spouses may likely exist only under special circumstances. 
Acknowledgments This paper was based on a presentation in the "Gendered Inequalities in Evolutionary Perspective" session at the 2007 American Anthropological Association annual meeting, organized by Rebecca Bliege Bird and Monique Borgerhoff Mulder. We are grateful for the helpful comments from five anonymous reviewers. Special thanks to the Tsimane in many communities who have graciously collaborated with us over the years. Research was supported by grants from the National Science Foundation (NSF) [BCS-0136274, BCS-0422690] and the National Institutes of Health (NIH/NIA) [R01AG024119-01].

Open Access This article is distributed under the terms of the Creative Commons Attribution Noncommercial License which permits any noncommercial use, distribution, and reproduction in any medium, provided the original author(s) and source are credited.

\section{Appendix}

Sexual division of productive labor among Tsimane. The percentage of total taskspecific observations where males and/or females participated, and the average minutes per day each sex engaged in those activities. The bold numbers indicate which sex allocates more time to the particular activity. Subtotals by sex for each category of labor are italicized.

\begin{tabular}{|c|c|c|c|c|c|}
\hline \multirow[t]{2}{*}{ CATEGORY/Activity } & \multicolumn{2}{|c|}{$\%$ by Sex } & \multicolumn{2}{|c|}{ Avg. Min/Day } & \multirow[t]{2}{*}{ No. of Time Point } \\
\hline & Male & Female & Male & Female & \\
\hline \multicolumn{6}{|l|}{ WAGE LABOR } \\
\hline Logging & 100 & 0 & 56 & 0 & 1,168 \\
\hline Merchant & 100 & 0 & 3 & 0 & 65 \\
\hline Other (cook, translator) & 85 & 15 & 2 & 0 & 52 \\
\hline Anthropologist & 84 & 16 & 2 & 0 & 43 \\
\hline Bolivian national, field labor & 100 & 0 & 2 & 0 & 36 \\
\hline \multirow[t]{2}{*}{ School teacher } & 100 & 0 & 2 & 0 & 36 \\
\hline & 99 & 1 & 67 & 1 & 1,400 \\
\hline \multicolumn{6}{|l|}{ CHILDCARE } \\
\hline Holding & 11 & 89 & 3 & 30 & 629 \\
\hline Suckling & 0 & 100 & 0 & 12 & 233 \\
\hline Tending, coo, fan & 15 & 85 & 1 & 5 & 124 \\
\hline Grooming hair & 5 & 95 & 0 & 6 & 111 \\
\hline Swinging & 8 & 92 & 0 & 4 & 86 \\
\hline Kiss or hug & 19 & 81 & 1 & 4 & 81 \\
\hline Feeding & 17 & 83 & 1 & 3 & 69 \\
\hline Play & 27 & 73 & 1 & 2 & 48 \\
\hline Grooming body & 4 & 96 & 0 & 2 & 47 \\
\hline Reprimanding, scolding & 22 & 78 & 0 & 1 & 32 \\
\hline Comforting & 20 & 80 & 0 & 1 & 30 \\
\hline Dressing & 4 & 96 & 0 & 1 & 26 \\
\hline \multirow[t]{2}{*}{ Bathing } & 0 & 100 & 0 & 1 & 15 \\
\hline & 10 & 90 & 7 & 74 & 1,531 \\
\hline \multicolumn{6}{|l|}{ OTHER FOOD ACQUISITION } \\
\hline Overnight foraging trip & 63 & 37 & 9 & 6 & 289 \\
\hline Foraging, collecting & 49 & 51 & 4 & 5 & 187 \\
\hline
\end{tabular}




\begin{tabular}{|c|c|c|c|c|c|}
\hline \multirow[t]{2}{*}{ CATEGORY/Activity } & \multicolumn{2}{|c|}{$\%$ by Sex } & \multicolumn{2}{|c|}{ Avg. Min/Day } & \multirow[t]{2}{*}{ No. of Time Points } \\
\hline & Male & Female & Male & Female & \\
\hline Commercial (buy/sell) & 73 & 28 & 7 & 3 & 90 \\
\hline Domestic animal care & 46 & 54 & 2 & 2 & 85 \\
\hline \multirow[t]{2}{*}{ Visit merchant } & 27 & 73 & 0 & 0 & 11 \\
\hline & 60 & 40 & 22 & 17 & 772 \\
\hline
\end{tabular}

MANUFACTURE

General, other

Palm thatch roof panels

Bring palm thatch

$\begin{array}{rrrrr}\mathbf{5 7} & 43 & 8 & 7 & 310 \\ 43 & \mathbf{5 7} & 4 & 6 & 209 \\ \mathbf{6 2} & 38 & 6 & 4 & 203 \\ 14 & \mathbf{8 6} & 1 & 7 & 151 \\ 0 & \mathbf{1 0 0} & 0 & 8 & 143 \\ 0 & \mathbf{1 0 0} & 0 & 7 & 129 \\ \mathbf{8 7} & 13 & 5 & 1 & 119 \\ \mathbf{7 4} & 26 & 3 & 1 & 91 \\ \mathbf{9 0} & 10 & 3 & 0 & 62 \\ \mathbf{9 6} & 4 & 3 & 0 & 56 \\ \mathbf{8 5} & 15 & 1 & 0 & 33 \\ \mathbf{9 7} & 3 & 1 & 0 & 32 \\ \mathbf{8 8} & 12 & 1 & 0 & 25 \\ 0 & \mathbf{1 0 0} & 0 & 0 & 7 \\ 49 & 51 & 37 & 43 & 1,574\end{array}$

Weave fans, mats

Carrying bag (saraij)

Spin thread

Build house

Repair tools

Canoe

Hunting tools

Get other materials

Fishing tools

Get housing materials

Prepare paint (de-seed)

HUNT

Hunt, unspecified

$\begin{array}{rrrrr}\mathbf{8 9} & 11 & 15 & 2 & 356 \\ \mathbf{1 0 0} & 0 & 11 & 0 & 225 \\ \mathbf{1 0 0} & 0 & 10 & 0 & 201 \\ \mathbf{1 0 0} & 0 & 5 & 0 & 105 \\ \mathbf{8 9} & 11 & 3 & 0 & 72 \\ 95 & 5 & 44 & 3 & 959\end{array}$

DOMESTIC

Sewing/mending clothes

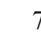

Clean

Get water

Tend fire

Firewood

Clear floor

Carries or brings objects

Sharpen (ie; stick or knife)

Shooing animals

Put things away

Tying knots, other materials

77

2

7

(1)

FARMING

Harvest

0

Chop (machete) 


\begin{tabular}{lllll}
\hline CATEGORY/Activity & \% by Sex & & Avg. Min/Day & No. of Time Points \\
\cline { 5 - 6 } & Male Female & Male Female & \\
\hline
\end{tabular}

\begin{tabular}{|c|c|c|c|c|c|}
\hline Plant & 67 & 33 & 6 & 3 & 174 \\
\hline Clear & 74 & 26 & 3 & 1 & 95 \\
\hline Weed & 93 & 7 & 2 & 0 & 54 \\
\hline Unspecific & 64 & 36 & 2 & 1 & 50 \\
\hline \multirow[t]{2}{*}{ Burn } & 50 & 50 & 0 & 0 & 4 \\
\hline & 58 & 42 & 41 & 33 & 1,473 \\
\hline \multicolumn{6}{|l|}{ FOOD PROCESSING } \\
\hline Cooking, active & 15 & 85 & 3 & 17 & 369 \\
\hline Cooking, passive & 13 & 87 & 2 & 16 & 341 \\
\hline Peeling roots & 15 & 85 & 1 & 9 & 189 \\
\hline Cutting & 23 & 77 & 2 & 7 & 178 \\
\hline Pounding & 23 & 77 & 1 & 5 & 115 \\
\hline Chewing & 21 & 79 & 1 & 4 & 101 \\
\hline Grinding & 4 & 96 & 0 & 5 & 99 \\
\hline Sifting & 33 & 67 & 2 & 4 & 99 \\
\hline Make fermented beverage (chicha) & 0 & 100 & 0 & 4 & 82 \\
\hline Mashing & 11 & 89 & 0 & 3 & 57 \\
\hline Degraining corn & 44 & 56 & 1 & 2 & 54 \\
\hline Serving food, beverage & 12 & 88 & 0 & 2 & 51 \\
\hline Processing, nonspecific & 30 & 70 & 1 & 2 & 50 \\
\hline Butcher/pluck & 32 & 68 & 1 & 2 & 50 \\
\hline Straining & 3 & 97 & 0 & 2 & 37 \\
\hline Drying & 13 & 88 & 0 & 2 & 32 \\
\hline Scraping & 19 & 81 & 0 & 1 & 27 \\
\hline Cooking, unknown & 0 & 100 & 0 & 1 & 25 \\
\hline Shelling rice & 29 & 71 & 0 & 1 & 17 \\
\hline Chicha food process & 14 & 86 & 0 & 1 & 14 \\
\hline Prepare animals for slaughter & 40 & 60 & 0 & 0 & 5 \\
\hline \multirow[t]{2}{*}{ Slaughter } & 25 & 75 & 0 & 0 & 4 \\
\hline & 17 & 83 & 16 & 89 & 1,996 \\
\hline \multicolumn{6}{|l|}{ FISHING } \\
\hline Hook and line & 66 & 34 & 13 & 7 & 397 \\
\hline Overnight fishing trip & 53 & 47 & 6 & 5 & 217 \\
\hline Bow and arrow & 87 & 13 & 8 & 1 & 180 \\
\hline Group barbasco (poison) & 65 & 35 & 5 & 3 & 157 \\
\hline Technique unknown & 81 & 19 & 6 & 2 & 147 \\
\hline Net & 87 & 13 & 1 & 0 & 30 \\
\hline \multirow[t]{2}{*}{ Dig/collect barbasco (poison) } & 100 & 0 & 0 & 0 & 6 \\
\hline & 69 & 31 & 38 & 19 & 1,134 \\
\hline Total direct and indirect production & 50 & 50 & 289 & 321 & 11,971 \\
\hline
\end{tabular}




\section{References}

Aiello, L., \& Wheeler, P. (1995). The expensive-tissue hypothesis: The brain and the digestive system in human and primate evolution. Current Anthropology, 36, 199-221.

Arendell, T. (1986). Mothers and divorce: Legal, economic and social dilemmas. Berkeley, CA: University of California Press.

Becker, G. S. (1973). A theory of marriage, part I. Journal of Political Economy, 81, 813-846.

Becker, G. S. (1974). A theory of marriage, part II. Journal of Political Economy, 81, S11-S26.

Becker, G. S. (1991). A treatise on the family (enlarge ed.). Cambridge, MA: Harvard University Press.

Bentley, G., Jasienska, G., \& Goldberg, T. (1993). Is the fertility of agriculturalists higher than that of nonagriculturalists? Current Anthropology, 34, 778-785.

Bergstrom, T. (1997). A survey of theories of the family. In M. R. Rosenzweig \& O. Stark (Eds.), Handbook of population and family economics, Vol. 1, pp. 21-79. Amsterdam: Elsevier.

Betzig, L. (1989). Causes of conjugal dissolution: A cross-cultural study. Current Anthropology, $30,654$.

Bird, D. W., \& Bliege Bird, R. (2002). Children on the reef: Slow learning or strategic foraging? Human Nature, 13, 269-297.

Bird, D. W., \& Bliege Bird, R. (2005). Mardu children's hunting strategies in the Western Desert, Australia: Foraging and the evolution of human life histories. In B. S. Hewlett \& M. E. Lamb (Eds.), Hunter-gatherer childhoods, pp. 129-146. New York: Aldine de Gruyter.

Bliege Bird, R. (1999). Cooperation and conflict: The behavioral ecology of the sexual division of labor. Evolutionary Anthropology, 8, 65-75.

Blurton Jones, N., Marlowe, F. W., Hawkes, K., \& O’Connell, J. F. (2000). Hunter-gatherer divorce rates and the paternal investment theory of human pair-bonding. In L. Cronk, N. Chagnon \& W. Irons (Eds.), Human behavior and adaptation: An anthropological perspective, pp. 69-90. Hawthorne, NY: Aldine de Gruyter.

Buss, D. M., \& Barnes, M. (1986). Preferences in human mate selection. Journal of Personality and Social Psychology, 50, 559-570.

Chase, I. D. (1980). Cooperative and noncooperative behavior in animals. American Naturalist, 115, 827857.

Chicchón, A. (1992). Chimane resource use and market involvement in the Beni Biosphere Reserve, Bolivia. Ph.D. dissertation, University of Florida, Gainesville.

Collier, J. F., \& Rosaldo, M. (1981). Politics and gender in simple societies. In S. B. Ortner \& H. Whitehead (Eds.), Sexual meanings. The cultural construction of gender and sexuality, pp. 275-329. Cambridge: Cambridge University Press.

Cordain, L., Watkins, B. A., \& Mann, N. J. (2001). Fatty acid composition and energy density of foods available to African hominds: Evolutionary implications for human brain development. World Review of Nutrition and Dietetics, 90, 144-161.

Demment, M. W., Young, M. M., \& Sensenig, R. L. (2003). Providing micronutrients through food-based solutions: A key to human and national development. Journal of Nutrition, 133, s3879-s3885.

Durkheim, E. (1933). The division of labor in society. George Simpson, trans. New York: Free Press.

Ember, C. (1978). Myths about hunter-gatherers. Ethnology, 17, 439-448.

Gaulin, S. J. C., \& Schlegel, A. (1980). Paternal confidence and paternal investment: A cross-cultural test of a sociobiological hypothesis. Ethology and Sociobiology, 1, 301-309.

Gottman, J. M. (1994). What predicts divorce? The relationship between marital processes and marital outcomes. Hillsdale, NJ: Lawrence Erlbaum Associates.

Gurven, M., \& Kaplan, H. S. (2006). Determinants of time allocation to production across the lifespan among the Machiguenga and Piro Indians of Peru. Human Nature, 17, 1-49.

Gurven, M., \& von Rueden, C. (2006). Hunting, social status and biological fitness. Biodemography and Social Biology, 53, 1-19.

Gurven, M., \& Walker, R. (2006). Energetic demand of multiple dependents and the evolution of slow human growth. Proceedings of the Royal Society of London, Series B: Biological Sciences, 273, 835841.

Gurven, M., \& Kaplan, H. S. (2007). Longevity among hunter-gatherers: A cross-cultural comparison. Population and Development Review, 33, 321-365.

Gurven, M., \& Winking, J. (2008). Collective action in action: Pro-social behavior in and out of the laboratory. American Anthropologist, 110, 179-190.

Gurven, M., \& Hill, K. (2009). Why do men hunt? A re-evaluation of "Man the Hunter" and the sexual division of labor. Current Anthropology, 50, 51-74. 
Gurven, M., Kaplan, H., \& Gutierrez, M. (2006). How long does it take to become a proficient hunter? Implications for the evolution of delayed growth. Journal of Human Evolution, 51, 454-470.

Gurven, M., Kaplan, H., \& Zelada Supa, A. (2007). Mortality experience of Tsimane Amerindians: Regional variation and temporal trends. American Journal of Human Biology, 19, 376-398.

Hadfield, G. K. (1999). A coordination model of the sexual division of labor. Journal of Economic Behavior and Organization, 40, 125-153.

Hagen, E. H. (1999). The functions of postpartum depression. Evolution and Human Behavior, 20, 325359.

Harris, M., \& Ross, E. B. (eds). (1987). Food and evolution: Toward a theory of human food habits. Philadelphia: Temple University Press.

Hawkes, K. (1993). Why hunter-gatherers work: An ancient version of the problem of public goods. Current Anthropology, 34, 341-361.

Hawkes, K., \& Bliege Bird, R. L. (2002). Showing off, handicap signaling, and the evolution of men's work. Evolutionary Anthropology, 11, 58-67.

Hendrix, L., \& Pearson, W. (1995). Spousal interdependence, female power, and divorce: A cross-cultural examination. Journal of Comparative Family Studies, 26, 217-232.

Hewlett, B. S. (1991). Demography and childcare in preindustrial societies. Journal of Anthropological Research, 47, 1-37.

Hewlett, B. S. (1992). Husband-wife reciprocity and the father-infant relationship among Aka Pygmies. In B. Hewlett (Ed.), Father-child relations: Cultural and biosocial contexts, pp. 153-176. New York : Aldine de Gruyter.

Hill, K., \& Hurtado, A. M. (1996). Ache life history: The ecology and demography of a foraging people. New York: Aldine de Gruyter.

Hurtado, A. M., \& Hill, K. (1992). Paternal effects on child survivorship among Ache and Hiwi huntergatherers: Implications for modeling pair-bond stability. In B. Hewlett (Ed.), Father-child relations: Cultural and biosocial contexts, pp. 36-54. New York: Aldine de Gruyter.

Hurtado, A. M., Hawkes, K., Hill, K., \& Kaplan, H. (1985). Female subsistence strategies among Ache hunter-gatherers of eastern Paraguay. Human Ecology, 13, 1-28.

Hurtado, A. M., Lambourne, C. A., Hill, K. R., \& Kessler, K. (2006). The public health implications of maternal care trade-offs. Human Nature, 17, 129-154.

Jochim, M. (1988). Optimal foraging and the division of labor. American Anthropologist, 90, 130-136.

Kaplan, H. (1994). Evolutionary and wealth flows theories of fertility: Empirical tests and new models. Population and Development Review, 20, 753-791.

Kaplan, H., \& Lancaster, J. B. (2003). An evolutionary and ecological analysis of human fertility, mating patterns and parental investment. In K. W. Wachter \& R. A. Bulatao (Eds.), Offspring: Fertility behavior in biodemographic perspective, pp. 170-223. Washington, DC: National Academies Press.

Kaplan, H., Hill, K., Lancaster, J. B., \& Hurtado, A. M. (2000). A theory of human life history evolution: Diet, intelligence, and longevity. Evolutionary Anthropology, 9, 156-185.

Kelly, R. L. (1983). Hunter-gatherer mobility strategies. Journal of Anthropological Research, 39, 277306.

Kramer, K. L. (2005). Children's help and the pace of reproduction: Cooperative breeding in humans. Evolutionary Anthropology, 14, 224-237.

Lancaster, J. B. (1978). Carrying and sharing in human evolution. Human Nature Magazine, 1, 82-89.

Larsen, C. S. (2003). Animal source foods and human health during evolution. Journal of Nutrition, 133, s3893-s3897.

Lundberg, S., \& Pollak, R. A. (1993). Separate spheres bargaining and the marriage market. Journal of Political Economy, 101, 988-1010.

Lundberg, S., \& Pollak, R. A. (1994). Noncooperative bargaining models of marriage. American Economic Review, 84, 132-137.

Manser, M., \& Brown, M. (1980). Marriage and household decision-making: A bargaining analysis. International Economic Review, 21, 31-44.

Marlowe, F. W. (2003). A critical period for provisioning by Hadza men: Implications for pair bonding. Evolution and Human Behavior, 24, 217-229.

Marlowe, F. W. (2004). The mating system of hunter-gatherers in the standard cross-cultural atlas. CrossCultural Research, 37, 282-306.

Marlowe, F. W. (2005). Mate preferences among Hadza hunter-gatherers. Human Nature, 15, 364-375.

Marlowe, F. W. (2007). Hunting and gathering: The human sexual division of labor. Cross-Cultural Research, 41, 170-195.

Maynard Smith, J. (1977). Parental investment: A prospective analysis. Animal Behavior, 25, 1-9. 
McElroy, M. B., \& Horney, M. J. (1981). Nash-bargained household decisions: Toward a generalization of the theory of demand. International Economic Review, 22, 333-349.

Milton, K. (2003). The critical role played by animal source foods in human (Homo) evolution. Journal of Nutrition, 133, s3886-s3892.

Murdock, G. P. (1967). Ethnographic atlas: A summary. Ethnology, 6, 109-236.

Murdock, G. P., \& Provost, C. (1973). Factors in the division of labor by sex: A cross-cultural analysis. Ethnology, 12, 203-225.

Neumann, C. G., Bwibo, N. O., Murphy, S. P., Sigman, M., Whaley, S., Allen, L. H., et al. (2003). Animal source foods improve dietary quality, micronutrient status, growth and cognitive function in Kenyan schoolchildren: Background, study design and baseline findings. Journal of Nutrition, 133, s3941s3949.

Ohtsuka, R. (1989). Hunting activity and aging among the Gidra Papuans: A biobehavioral analysis. American Journal of Physical Anthropology, 80, 31-39.

Panter-Brick, C. (2002). Sexual division of labor: Energetic and evolutionary scenarios. American Journal of Human Biology, 14, 627-640.

Pearl, J. (2000). Causality: Models, reasoning and inference. New York: Cambridge University Press.

Pearson, W,. Jr, \& Hendrix, L. (1979). Divorce and the status of women. Journal of Marriage and the Family, 41, 375-385.

Pennington, R., \& Harpending, H. (1988). Fitness and fertility among the Kalahari !Kung. American Journal of Physical Anthropology, 77, 303-319.

Pillsworth, E. (2008). Mate preferences among the Shuar of Ecuador: Trait rankings and peer evaluations. Evolution and Human Behavior, 29, 256-267.

Quinlan, R. J., \& Quinlan, M. B. (2007). Evolutionary ecology of human pair-bonds: Cross-cultural tests of alternative hypotheses. Cross-Cultural Research, 412, 149-169.

Rapoport, R. (1966). Two-person game theory: The essential ideas. Ann Arbor: University of Michigan Press.

Reyes-García, V. (2001). Indigenous people, ethnobotanical knowledge, and market economy: A case study of the Tsimane' Amerindians of lowlands Bolivia. Unpublished Ph.D. dissertation, University of Florida, Gainesville.

Rucas, S. L., Gurven, M., Kaplan, H., Winking, J., Gangestad, S., \& Crespo, M. (2006). Female intrasexual competition and reputational effects on attractiveness among the Tsimane of Bolivia. Evolution and Human Behavior, 27, 40-52.

Sanday, P. R. (1981). Female power and male dominance. Cambridge: Cambridge University Press.

Schoen, R., \& Weinick, R. M. (1993). Partner choice in marriages and cohabitations. Journal of Marriage and the Family, 55, 408-414.

Schoen, R., \& Cheng, Y.-H. (2006). Partner choice and the differential retreat from marriage. Journal of Marriage and the Family, 68, 1-10.

Schwagmeyer, P. L., Mock, D. W., \& Parker, G. A. (2002). Biparental care in house sparrows: Negotiation or sealed bid? Behavioral Ecology, 13, 713-721.

Schwartz, C. R., \& Mare, R. D. (2005). Trends in educational assortative marriage from 1940 to 2003. Demography, 42, 621-646.

Sear, R., \& Mace, R. (2007). Who keeps children alive? A review of the effects of kin on child survival. Evolution and Human Behavior, 29, 1-18.

Tucker, B., \& Young, A. G. (2005). Growing up Mikea: Children's time allocation and tuber foraging in southwestern Madagascar. In B. Hewlett \& M. Lamb (Eds.), Hunter-gatherer childhoods, pp. 147171. New York: Aldine de Gruyter.

von Rueden, C., Gurven, M., \& Kaplan, H. (2008). The multiple dimensions of male social status in an Amazonian society. Evolution and Human Behavior, 29, 402-415.

Walker, R., Hill, K., Kaplan, H., \& McMillan, G. (2002). Age-dependency in skill, strength and hunting ability among the Ache of eastern Paraguay. Journal of Human Evolution, 42, 639-657.

Waynforth, D. (2001). Mate-choice trade-offs and women's preference for physically attractive men. Human Nature, 12, 207-220.

Winking, J. (2006). Are men that bad as fathers? The role of men's investments. Social Biology, 53, 100115.

Winking, J., Kaplan, H., Gurven, M., \& Rucas, S. (2007). Why do men marry and why do they stray? Proceedings of the Royal Society, B: Biological Sciences, 274, 1643-1649.

Winking, J., Gurven, M., Kaplan, H., and Stieglitz, J. (2009). The goals of direct paternal care among a South Amerindian population. American Journal of Physical Anthropology. doi:10.1002/ajpa.20981.

Winkler, D. W. (1987). A general model for parental care. American Naturalist, 130, 526-543. 
Zuk, M., Ligon, J. D., \& Thornhill, R. (1992). Effects of experimental manipulation of male secondary sex characters on female mate preference in red jungle fowl. Animal Behaviour, 44, 999-1006.

Michael Gurven is an associate professor of anthropology at University of California-Santa Barbara. He received his Ph.D. from the University of New Mexico in 2000. He has conducted fieldwork in Paraguay and Bolivia with Ache and Tsimane forager-horticulturalists. His research interests include intra-group cooperation and problems of collective action, and the application of life history theory to explain human longevity, development, and sociality. Since 2002, Gurven and Kaplan have co-directed the Tsimane Health and Life History Initiative to further develop theory and test implications of different models of human life history evolution.

Jeffrey Winking is an assistant professor of anthropology at Texas A\&M University. He received his Ph.D. from the University of New Mexico in 2005. His research has focused on men's reproductive and parenting decisions, based on fieldwork among Tsimane forager-horticulturalists in Bolivia.

Hillard Kaplan is a professor of anthropology at University of New Mexico. He received his Ph.D. from the University of Utah in 1983. He has conducted fieldwork in Paraguay, Brazil, Botswana, and Bolivia. His research interests include evolutionary perspectives on life course development and senescence, and brain evolution. He has applied human capital theory towards explaining human life history evolution, and the proximate physiological and psychological mechanisms governing fertility and parental investment in both traditional, high-fertility, subsistence economies and modern, low-fertility, industrial societies.

Chris von Rueden is a Ph.D. candidate in the Department of Anthropology at University of CaliforniaSanta Barbara. He is currently conducting fieldwork with the Tsimane forager-horticulturalists of Bolivia, studying social status across the life course, the effects of status on health and fertility, and leadership as a solution to collective action problems.

Lisa McAllister is a Ph.D. candidate in the Department of Anthropology at University of California-Santa Barbara. She has conducted fieldwork in Bolivia and Belize and is studying fertility transition and reproductive decision-making from an evolutionary perspective. 